J. Product. \& Dev., 23(3): 453-481(2018)

\title{
EFFECT OF IRRIGATION LEVELS WITH FOLIAR SPRAY OF SILICON, CALCIUM AND AMINO ACIDS ON "THOMPSON SEEDLESS" GRAPEVINE. II. ENHANCING QUALITY AND STORABILITY
}

\author{
Saber S. Bassiony ${ }^{1}$, Ali E. Zaghloul ${ }^{2}$ and Maha H. Abd El-Aziz, \\ ${ }^{I}$ Viticulture Res. Dept. Horticulture Research Institute ARC, Giza, Egypt \\ ${ }^{2}$ Handling Res. Dept. Horticulture Research Institute ARC, Giza, Egypt
}

\section{ABSTRACT}

This study was conducted during two growing seasons of 2016 and 2017 to evaluate the potential effects of different irrigation levels: 30,50 and $70 \%$ depleted of available soil water $\left(I_{1}, I_{2}\right.$ and $I_{3}$, respectively) after fruit set as well as four foliar applications of Control, Silicon spray at 1.5 $\mathrm{g} / \mathrm{L}$, Calcium nitrate at $1 \mathrm{~g} / \mathrm{L}$ and Amino acids at $2 \mathrm{ml} / \mathrm{L}$ (S1, S2, S3 and $S 4$, respectively), which started at $15-20 \mathrm{~cm}$ of shoot length and the second one after fruit set, then these were continuous every two weeks till veraison stage on fruit quality and storability of "Thompson seedless" (Vitis vinifera L.) grapevines grown in clay soil under flow irrigation system in El-Mahalla region Gharbia Governorate.

The obtained results revealed that, vines irrigated at $I_{1}$ and $I_{2}$ recorded a significant increase in berry physical quality parameters in terms of firmness, removal force, berry shatter and chemicals as SSC\%, acidity and SSC/acid ratio. However, irrigation at $I_{3}$ recorded the lowest percent of cluster weight loss until the end of storage period. Calcium as well as silicon sprays, enhanced berry firmness, berry removal force and reduced berries shattering at picking date and during the cold storage period. Moreover, calcium application was more effective in increasing SSC/acid ratio, cluster quality index and marketable cluster percent and reducing physiological weight loss during storage. Foliar spray with amino acids recorded the highest significant values of SSC\% and acidity and reduced the decayed berries\% at the end of storage period.

The combination between $I_{1}$ or $I_{2}$ irrigation levels and calcium spray treatments were more effective in enhancing berry firmness, berry removal force, SSC/acid ratio, rachis browning index and marketable cluster percent and reduced shattered berries, decayed berries and cluster weight loss till 60 days of cold storage.

Keywords: Irrigation, Silicon, Calcium, Amino acids, Storability, fruit quality and Thompson seedless. 


\section{INTRODUCTION}

Grapevine (Vitis vinifera L.) is the most important fruit crop in the world. Good irrigation system is an important agricultural practice thus resulted in maintaining good vegetative growth and productivity of grapevines, as intensive irrigation leads to slow growth of roots and the emergence of symptoms of deficiency of different nutrients as a result of their leaching from the rihzo-sphere moreover, excessive water irrigation promotes root rot especially under clay soils. On contrary, deficit irrigation water results in drought stress that led to reducing of yield, fruit quality (Maughan et at., 2017). So there is a great need for more studies to improve the use of water not only to achieve sustainable agriculture but also to reduce the loss of irrigation water (Martínez-de-Toda and Balda, 2013). Several researchers showed different horticultural practices that can help to reduce the amount of irrigation water without deterioration effect on vine vigor and berries quality characters, as amino acids (Pradeep and Elamathi, 2007), silicon (Meena et al., 2014) and calcium (Upadhyaya et al., 2011) applications.

Recently, the use of natural materials as silicon has been spread to replace the chemicals and this substitution is due to increased resistance to the pathogenesis of chemical compounds as well as to preserve the environment and public health (Dhekney, 2016). Silicon plays an important role in plant biology as shown by several researchers (Meunier et al., 2011, Meena et al., 2014 and Shahidian et al., 2016), where it helps plant mitigating numerous of stresses factors as biotic and abiotic stresses. It is also known for enhancing drought tolerance of plants through maintaining water balance of plant and structure of xylem vessels under high transpiration. Moreover, foliar silicon supply on grapes, cucumber, and zucchini squash revealed benefits of this element to resistance against disease (Bhavya et al., 2010). Also, silicon plays an essential role in influential grape berry quality as color and flavor. Moreover, it prevents berries softening by affecting activities of major cell wall degrading enzymes such as cellulase, polygalacturonase and xylanase (Jiao-jing et al., 2009). Also, foliar application of silicon was effective in enhancing different grape berries quality parameters viz., total sugar, reducing sugar, non reducing sugars, total soluble solids, acidity, cluster weight loss and decayed berries percent during cold storage period (Bhavya et al., 2010).

Amino acids are known that amino acids have several anti-oxidative properties which play an essential role in supporting the plant in mitigate oxidative stress under unfavorable conditions. Application of amino acids generally enhancing biosynthesis of proteins also delay fruit cells senescence, preventing lipids of plasma membrane from oxidation by the free radicals which reduced the loss of permeability which retard the incidence of disorders. 
Moreover, it plays an important role as a stimulator of natural hormones biosyntheses like IAA, GA3, cytokinins and ethylene also enzymes and cell division these encouraging properties reflected on trees and fruits (Davis, 1982, Rai, 2002 and Abdel-Mawgoud et al., 2011). Application of amino acids not only enhanced the vegetative growth but also increase yield and maintain the fruit quality through improving the biosynthesis of all plant organic matter and put forward maximum protection against different stresses factors (Ahmed et al., 2011). Amino acids showed a positive effect on some fruits quality during storage as reported by Khosroshahi et al. (2007) who concluded that, foliar application of polyamines to mango trees enhanced fruit quality through some changes in fruit firmness, fruit weight loss, ethylene production, soluble solids content, and total titratable acids. Also, exogenously applied of Putrescine reduced fruit deterioration and increased the shelf life of lemon (MartínezRomero et al., 1999).

Calcium is considered as an important eliminate for stabilizing cell wall, construction of membrane and its functions. This positive effect enhancing fruit quality as stated by several researchers (Kluter et al., 2006, and Raese \& Drake, 2008) they reported that, preharvest $\mathrm{Ca}$ sprays treatments used to increase $\mathrm{Ca}$ content of the fruit cell wall were effective in delaying senescence, resulting in firmer fruits. Also, Marzouk and Kassem (2011) concluded that, spraying calcium chloride on Thompson seedless grapevines was effective in increased berries firmness and decreased the percentage of unmarketable clusters after storage at ambient temperature for seven days. Moreover, pretreatments of these salts are maintaining the quality characteristics of different fruits such as grapes, apples and mangoes (Yousefi et al., 2015, Nigro et al., 2006 and Javed et al., 2015). Applications of calcium salts including calcium bicarbonates, chloride and nitrate are used successfully to replace fungicide in controlling the postharvest decays of grape berries (Romanazzi et al., 2012). In this way, AlQuarshi and Awad (2015) summarized that, foliar application of calcium chloride at $1 \%$ and ethanol at $10 \%$ on El-Bayadi table grapes was effective in reducing the incidence of berries decay.

Therefore, the present study was conducted to explaining the effect of pre-harvest foliar spray with silicon, calcium and amino acids on "Thompson seedless" grapevines grown under different irrigation levels on maintaining fruit quality under cold storage condition.

\section{MATERIALS AND METHODS}

This field experiment was applied during 2016 and 2017 growing seasons on ten years old, "Thompson seedless" grapevines (Vitis vinifera L.) 
established in a private vineyard located at El-Mahalla, Gharbiya Governorate, Egypt. Vines were grown at $1.5 \times 3$ meters in a row and between rows respectively, with flow irrigation system. Vines were pruned as cane pruning with modified $\mathrm{Y}$ shape supporting system. The total buds loads for each vine was adjusted to 84 eyes ( 7 fruiting canes $\times 10$ eyes plus 7 renewal spurs $\times$ two eyes). Normal cultural practices usually for vine in this area were done. The soil physical properties were measured according to (Jackson, 1973 and Klute, 1986), where soil texture was clay (58\% clay, $27 \%$ silt and $15 \%$ sand), soil $\mathrm{pH}$ 7.8 , EC $2.1 \mathrm{dSm}^{-1}$ and water table of soil was about $150 \mathrm{~cm}$. This experiment was planned to study the effect of irrigation water levels and foliar applications of silicon, calcium and amino acids on fruit quality and storability of "Thompson seedless" grapevine. The chosen vines were vigor, uniform and healthy as possible and arranged in a split plot design as follows.

The main plots were assigned for three irrigation levels as:

$\mathrm{I}_{1=}$ irrigation at $30 \%$ depletion of soil available water (control).

$\mathrm{I}_{2}=$ irrigation at $50 \%$ depletion of soil available water.

$\mathrm{I}_{3=}$ irrigation at $70 \%$ depletion of soil available water.

The sub plots were randomly assigned by four foliar sprays as:

$\mathrm{S}_{1=}$ foliar sprays with tap water (control).

$\mathrm{S}_{2=}$ foliar sprays with potassium silicate $\left(\mathrm{SiO}_{2} 25 \%+\mathrm{K}_{2} \mathrm{O} 10 \%\right)$ at $1.5 \mathrm{ml} / \mathrm{l}$

$\mathrm{S}_{3=}$ foliar sprays with Calcium nitrate $\left(\mathrm{CaO} 26 \%+\mathrm{NO}_{3} 15.5 \%\right)$ at $1.0 \mathrm{~g} / \mathrm{l}$.

$\mathrm{S}_{4=}$ foliar sprays with amino acids at $2 \mathrm{ml} / 1$ (commercial product containing: total amino acids $20 \%+$ magnesium $8 \%+$ sulfur $10.6 \%$ ).

The combinations between the two factors resulting twelve treatments ( 3 irrigation levels $\mathrm{x} 4$ foliar applications) each treatment replicated three times with three vines in each replicate (3 replicate $\mathrm{x} 3$ vines).

\section{Irrigation treatments}

Amount of irrigation water applied (WA) for each irrigation treatment was determined according to soil moisture content in soil samples taken from consecutive depth of $15 \mathrm{~cm}$ down to depth of $60 \mathrm{~cm}$ to reach its field capacity before conduct irrigation levels (at depletion of 30,50 and 70\% of AW) with $4569.6,2881.8$ and $2494.1 \mathrm{~m}^{3} / \mathrm{fed} / \mathrm{season}$ distributed on 16,9 and 7 irrigations, respectively as shown in Tables (1 and 2). Submerged orifice with fixed dimension was used to convey and measure the amount of water applied according to Michael (1978) as the following equation.

$$
\mathbf{Q}=\mathbf{C A} \sqrt{\mathbf{2 g h}}
$$

Where: Q=Discharge through the orifice (L/sec.), $\mathrm{C}=$ Coefficient of discharge $(0.61)$, A $=$ Cross section area of the orifice, $\mathrm{cm}^{2}, \mathrm{~g}=$ Acceleration due to gravity, $\mathrm{cm} / \mathrm{sec}^{2}(981$ $\mathrm{cm} / \mathrm{sec}^{2}$ ) and $\mathrm{h}=$ Pressure head, causing discharge through the orifice, $\mathrm{cm}$ 
Table (1): Some physical characteristics of soil and water constants for the studied vineyard at different soil depth (Average of the two growing seasons).

\begin{tabular}{lccc}
\hline \multirow{2}{*}{ Soil depth (cm) } & \multicolumn{3}{c}{ Soil water constants } \\
\cline { 2 - 4 } & $\begin{array}{c}\text { Field Capacity } \\
\text { (FC) \% }\end{array}$ & $\begin{array}{c}\text { Permanent Wilting Point } \\
\text { \% }\end{array}$ & $\begin{array}{c}\text { Available Water } \\
\text { \% }\end{array}$ \\
\hline $\mathbf{0 - 1 5}$ & 47.34 & 22.24 & 25.10 \\
$\mathbf{1 5}-\mathbf{3 0}$ & 43.83 & 20.34 & 23.49 \\
$\mathbf{3 0}-\mathbf{4 5}$ & 40.45 & 19.88 & 20.57 \\
$\mathbf{4 5}-\mathbf{6 0}$ & 37.77 & 18.50 & 20.27 \\
\hline
\end{tabular}

Table (2): The amount of irrigation water applied $\left(\mathrm{m}^{3} / \mathrm{fed}\right.$.) for different irrigation levels during each growing season.

\begin{tabular}{lccc}
\hline $\begin{array}{l}\text { Irrigation } \\
\text { treatments }\end{array}$ & $\begin{array}{c}\text { Irrigation } \\
\text { No. }\end{array}$ & $\begin{array}{c}\text { Amount of each } \\
\text { irrigation water } \\
\mathbf{m}^{3} / \text { fed. }\end{array}$ & $\begin{array}{c}\text { Water applied (WA) } \\
\mathbf{m}^{3} / \text { fed./season }\end{array}$ \\
\hline $\mathbf{3 0 \%}$ depleted Water & 16 & 285.6 & 4569.6 \\
$\mathbf{5 0 \%}$ depleted Water & 9 & 320.2 & 2881.8 \\
$\mathbf{7 0 \%}$ depleted Water & 7 & 356.3 & 2494.1 \\
\hline
\end{tabular}

Irrigation treatments were conducted after one week from fruit set. However, the first spray of foliar treatments was started when shoots reached $15-20 \mathrm{~cm}$ in length, and the second one was applied after fruit set and then were done continuously every two weeks till the veraison stage (4sprays/ season).

Thompson seedless clusters were harvested after 117 and 120 days of full bloom when berries juice SSC reached about $16 \%$ in both seasons, respectively. At harvesting time, bunches samples were taken at random from each replicate and directly transported to the laboratory of Sakha Horticulture Research Station, Kafr El-sheikh, Egypt. The clusters were packed in 50 x 30 x $15 \mathrm{~cm}$ carton boxes dimensions with slow- release $\mathrm{SO}_{2}$ pads to control decays during cold storage. The carton boxes were stored at $1{ }^{\circ} \mathrm{C}$ and $90-95 \% \mathrm{RH}$. All treatments were represented by three carton boxes $(2 \mathrm{~kg}$ of clusters per carton box as replicate) for every storage period. Three clusters/carton boxes were weighted and labeled at picking time to determine the cluster weight loss during each cold storage periods. $\mathrm{SO}_{2}$ pads were replaced with a new one every two weeks.

Fruits quality was determined at picking date (zero time of cold storage) and after every 15 days intervals up to 60 days of cold storage. Three-carton boxes/treatment was taken out to determining the following parameters:

\section{A. Berry physical quality characters}

- Berry firmness and berry removal force were measured in ten berries per cluster using the hand dynamometer apparatus model FDP1000 with a 
thump $1 \mathrm{~mm}$. The two parameters data were transformed into Newton units using transformed factor (1 gram-force $=0.00980665$ Newton).

- Berry shattering (\%) was determined as shattered berries weight percent of the cluster after given a two light shakes by hand.

- Berries decay (\%) was expressed as the decayed berries weight percent of cluster weight.

\section{B. Berry chemical characters}

- Berries juice soluble solids content (SSC) \% was estimated using the hand refractometer apparatus

- The titratable acidity (\%) was determined as mg of tartaric acid equivalent using titration by $\mathrm{Na} \mathrm{OH}(0.1 \mathrm{~N})$ in $100 \mathrm{ml}$ of berries juice as (A.O.A.C., 1990).

- SSC: Acid ratio was calculated using data of SSC \% and that of titratable acidity data.

\section{Cluster physical characters}

- Cluster weight loss during cold storage $(\%)$ was calculated using the three labeled clusters of carton boxes according to the following equation:

$$
\text { Cluster weight loss } \%=\frac{\mathrm{W} 0-\mathrm{W} 1}{\mathrm{~W} 0} \times 100
$$

Where: $\mathrm{W} 0=$ cluster weight at harvesting time, $\mathrm{W} 1=$ cluster weight after each storage periods $(15,30,45$ and 60 days)

- Rachis browning index during storage was estimated every 15 days of cold storage period till 60 days using the scale suggested by Crisisto et al. (2002) as follow:

1=Healthy (no browning found and the pedicels are green), 2=Slight (rachis showed browning in pedicels only), $3=$ Moderate (secondary rachis and pedicels showed browning) and $4=$ Severe (primary, secondary and pedicels of rachis completely brown).

- Marketable clusters (\%) were expressed as the percentage of the sound cluster weight without any decayed berries after storage in related to the initial fresh weight according to the following equation.

Marketable cluster $(\%)=($ sound cluster weight after storage period/ cluster fresh weight before storage) $\mathrm{x} 100$

- Cluster total qualities index (CTQI) calculated according to El-Abbasy (2006). This calculated as a sum of the absolute units for the values of SSC: acid ratio, marketable clusters (MC), berry firmness (F) and berry removal force $(\mathrm{RF})$. The absolute unit of value was calculated by dividing the measured parameter value by the highest recorded value for the same parameter in the same season. The author supposed that the cluster overall 
quality index equal: $(25 \% \mathrm{SSC}$ : acid ratio $+25 \%(\mathrm{MC})+25 \%(\mathrm{~F})+25 \%$ (RF)/4).

\section{Statistical analysis}

The experimental design was a split plot and all the collected data were statistically analyzed by the analysis of variance as described by Snedecor and Cochran (1990). The differences among treatments mean were compared using the least significant different L.S.D at 5\% level.

\section{RESULTS AND DISCUSSION}

\section{A. Berries physical quality characters}

\section{Berry firmness}

Data of Table (3) cleared that, irrigation at 30 and 50\% depletion of available soil water $\left(I_{1}\right.$ and $\left.I_{2}\right)$ were effective in enhancing berry firmness of "Thompson seedless" grape at picking date and throughout all cold storage period as compared with the more stress irrigation level $(70 \%$ depletion of available soil water $I_{3}$ ) which showed the lower significant values during both seasons. Moreover, all foliar spray applications $\left(S_{2}, S_{3}\right.$, and $\left.S_{4}\right)$ enhanced this character in a comparison to control at picking date and during cold storage in the two seasons. Foliar spray with calcium as well as silicon $\left(S_{3}\right.$ and $\left.S_{2}\right)$ cleared the highest significant values at picking date, but only calcium spray showed the highest significantly value by the end of the storage period (60 days) in the first season.

These treatments reached the higher values of berry firmness starting picking date till the end of storage time without significant between them in the second season. This results are in agreement with that of Chaves et al. (2007) they concluded that, it can be decrease the amount of water applied by $50 \%$ of available soil water as deficit irrigation or partial root drying without negative effects on yield and even get some gains of berries quality with the two grapevine varieties Moscate and Castela throughout three years. Moreover, several researchers cleared beneficial effect of calcium (Claudia and Rafael, 2010), silicon (Meena et al., 2014) and amino acids (Khosroshahi et al., 2007) foliar sprays on grape berries firmness under different abiotic (salinity, drought and deficit water) stresses.

Regarding the interaction, it could be noticed that, calcium foliar spray $\left(\mathrm{S}_{3}\right)$ in combined with all irrigated treatments showed significantly higher berry firmness at the initial time as well as during all storage periods compared with $\mathrm{S}_{1}$ during two seasons. However, the lower values were noticed with the interaction between $\mathrm{I}_{3}$ with $\mathrm{S}_{1}$ at picking date and at the end of storage with no significant differences between $S_{1}$ and $S_{2}$ under the same irrigation level 
Table (3): Effect of irrigation levels and foliar spray with silicon, calcium and amino acids on berry firmness of "Thompson seedless" grapevines during cold storage at $1^{\circ} \mathrm{C}$ and RH 90-95\% in 2016 and 2017 seasons

\begin{tabular}{|c|c|c|c|c|c|c|c|c|c|c|c|c|}
\hline \multirow{4}{*}{ Treatments } & \multirow{2}{*}{\multicolumn{4}{|c|}{2016}} & \multicolumn{4}{|c|}{ Berry firmness (Newton) } & \multirow{2}{*}{\multicolumn{2}{|c|}{2017}} & & \\
\hline & & & & & & & & & & & & \\
\hline & \multicolumn{5}{|c|}{ Cold storage periods in days } & & & \multicolumn{5}{|c|}{ Cold storage periods in days } \\
\hline & $\mathbf{0}$ & 15 & 30 & 45 & 60 & Mean & $\mathbf{0}$ & 15 & 30 & 45 & $\begin{array}{ll}60 & 1 \\
\end{array}$ & Mean \\
\hline \multicolumn{13}{|c|}{ Irrigation main effect } \\
\hline $\mathrm{I}_{1}$ & 3.36 & 3.25 & 3.12 & 2.93 & 2.84 & 3.10 & 4.58 & 4.43 & 4.32 & 4.15 & 3.80 & 4.26 \\
\hline $\mathbf{I}_{2}$ & 3.32 & 3.17 & 3.06 & 2.84 & 2.67 & 3.01 & 4.68 & 4.50 & 4.41 & 4.22 & 4.03 & 4.37 \\
\hline $\mathbf{I}_{3}$ & 2.80 & 2.63 & 2.40 & 2.20 & 2.04 & 2.41 & 3.51 & 3.33 & 3.13 & 2.88 & 2.68 & 3.11 \\
\hline LSD at $5 \%$ & 0.47 & 0.45 & 0.43 & 0.41 & 0.39 & 0.36 & 0.53 & 0.40 & 0.45 & 0.45 & 0.46 & 0.48 \\
\hline \multicolumn{13}{|c|}{$\overline{\text { Spray main effect }}$} \\
\hline$S_{1}$ & 2.89 & 2.75 & 2.60 & 2.41 & 2.31 & 2.59 & 3.81 & 3.63 & 3.48 & 3.23 & 2.96 & 3.42 \\
\hline $\mathbf{S}_{2}$ & 3.28 & 3.13 & 2.94 & 2.74 & 2.54 & 2.93 & 4.54 & 4.31 & 4.20 & 4.00 & 3.73 & 4.16 \\
\hline $\mathbf{S}_{3}$ & 3.49 & 3.33 & 3.25 & 3.12 & 2.98 & 3.23 & 4.64 & 4.53 & 4.37 & 4.17 & 3.90 & 4.32 \\
\hline $\mathrm{S}_{4}$ & 2.99 & 2.84 & 2.64 & 2.36 & 2.24 & 2.61 & 4.02 & 3.88 & 3.76 & 3.59 & 3.41 & 3.73 \\
\hline LSD at $5 \%$ & 0.274 & 0.280 & 0.262 & 0.271 & 0.273 & 0.266 & 0.252 & 0.282 & 0.243 & 0.252 & 0.256 & 0.240 \\
\hline \multicolumn{13}{|c|}{ Interaction } \\
\hline \multirow{5}{*}{$\begin{array}{lll} & & \mathbf{S}_{1} \\
& & \mathbf{S}_{1} \\
\mathbf{I}_{1} & & \mathbf{S} \\
& & \mathbf{S} \\
& & \mathbf{S}\end{array}$} & 3.11 & 3.03 & 2.86 & 2.63 & 2.65 & 2.86 & 4.01 & 3.77 & 3.60 & 3.33 & 2.96 & 3.53 \\
\hline & 3.55 & 3.42 & 3.35 & 3.22 & 3.00 & 3.31 & 4.96 & 4.79 & 4.68 & 4.45 & 4.15 & 4.61 \\
\hline & 3.64 & 3.54 & 3.47 & 3.37 & 3.30 & 3.46 & 5.03 & 4.91 & 4.83 & 4.72 & 4.22 & 4.74 \\
\hline & 3.14 & 3.00 & 2.81 & 2.51 & 2.39 & 2.77 & 4.33 & 4.26 & 4.18 & 4.09 & 3.87 & 4.15 \\
\hline & 3.15 & 3.00 & 2.87 & 2.77 & 2.65 & 2.89 & 4.30 & 4.06 & 3.94 & 3.74 & 3.58 & 3.92 \\
\hline \multirow{3}{*}{$\begin{array}{l}S \\
S \\
S\end{array}$} & 3.44 & 3.32 & 3.21 & 3.01 & 2.81 & 3.16 & 4.89 & 4.71 & 4.62 & 4.34 & 4.04 & 4.52 \\
\hline & 3.57 & 3.34 & 3.28 & 3.17 & 3.00 & 3.27 & 4.87 & 4.72 & 4.66 & 4.48 & 4.31 & 4.61 \\
\hline & 3.12 & 3.00 & 2.87 & 2.42 & 2.23 & 2.73 & 4.66 & 4.51 & 4.41 & 4.32 & 4.17 & 4.41 \\
\hline \multirow{4}{*}{$\mathbf{I}_{3}$} & 2.41 & 2.22 & 2.08 & 1.84 & 1.63 & 2.04 & 3.13 & 3.06 & 2.91 & 2.61 & 2.35 & 2.81 \\
\hline & 2.84 & 2.65 & 2.25 & 2.00 & 1.80 & 2.31 & 3.78 & 3.44 & 3.30 & 3.22 & 3.00 & 3.35 \\
\hline & 3.25 & 3.11 & 3.00 & 2.83 & 2.64 & 2.97 & 4.03 & 3.96 & 3.63 & 3.32 & 3.18 & 3.62 \\
\hline & 2.71 & 2.53 & 2.25 & 2.14 & 2.10 & 2.35 & 3.08 & 2.87 & 2.69 & 2.35 & 2.20 & 2.64 \\
\hline $\begin{array}{ll}\text { LSD at } & \text { I X S } \\
5 \% & \text { Days }\end{array}$ & 0.452 & 0.417 & $\begin{array}{l}0.430 \\
0.089\end{array}$ & 0.434 & 0.442 & 0.423 & 0.591 & 0.512 & $\begin{array}{l}0.504 \\
0.102\end{array}$ & 0.521 & 0.472 & 0.414 \\
\hline
\end{tabular}

in the first season. By the second one, the same trend was noticed with no significant differences between foliar spray with $S_{1}$ and $S_{4}$ when combined with $\mathrm{I}_{3}$ at picking date and thought all storage periods till the end of storage period. Similar results are in line with that of Amiri et al. (2009).

\section{Berry removal force}

Data of Table (4) showed that, vines irrigated control $\left(\mathrm{I}_{1}\right)$ as well as that of $I_{2}$, showed the higher berry removal force values without differences between them, however the lower value was cleared by vines under the $I_{3}$ level of irrigation with highly significant with the others. This trend was true at harvesting time and also at the end of storage period in both seasons. As for 
Table(4):Effect of irrigation levels and foliar spray with silicon, calcium and amino acids on berry removal force of "Thompson seedless" grapevines during cold storage at $1^{0} \mathrm{C}$ and $\mathrm{RH} 90-95 \%$ in 2016 and 2017 seasons

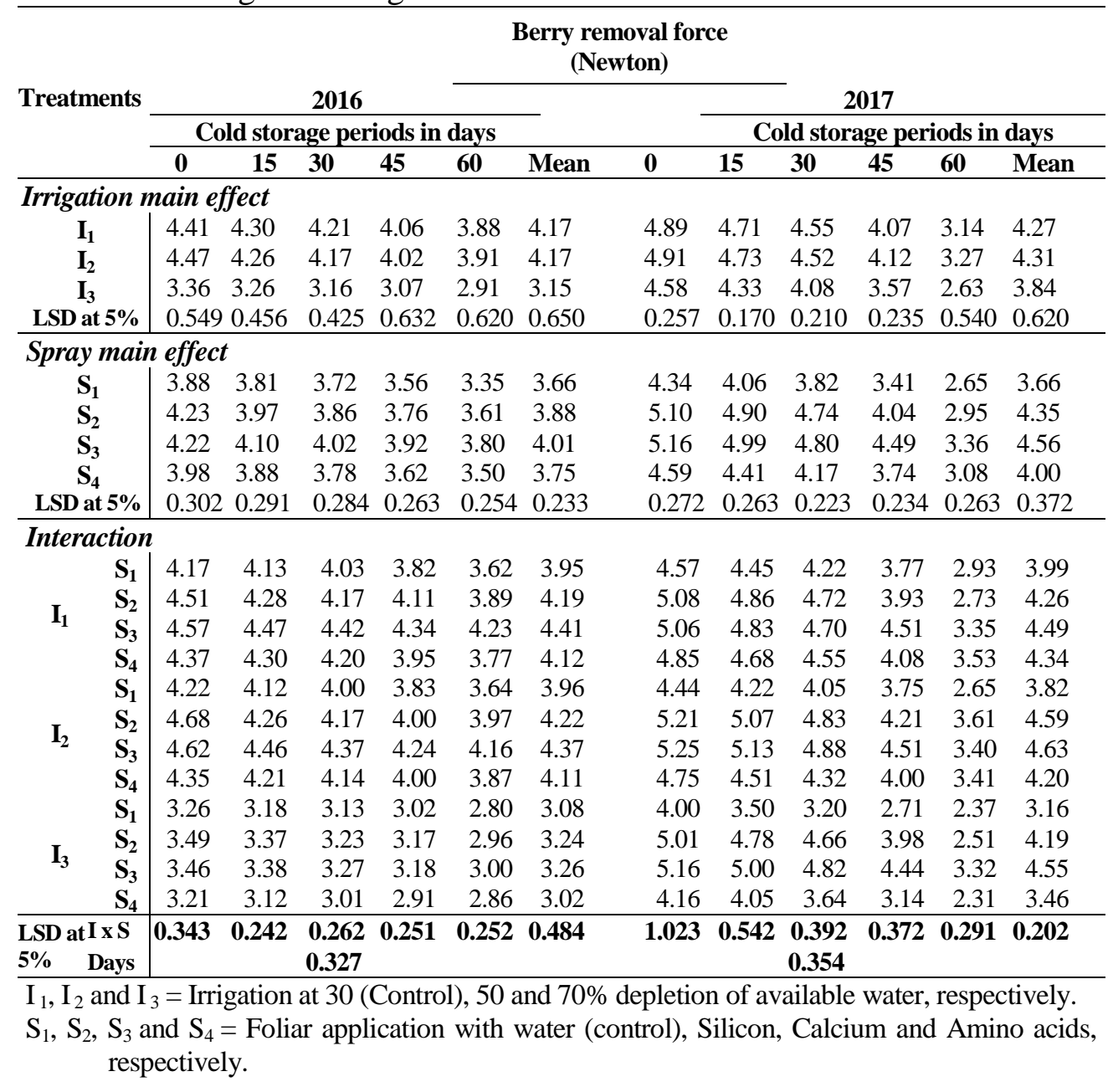

foliar spray applications, vines sprayed with calcium $\left(\mathrm{S}_{3}\right)$ and silicon $\left(\mathrm{S}_{2}\right)$ showed a significant increase in this character at picking date compared with $S_{1}$ during the two seasons and at the end of storage in the first season. The vine treated with S3 has recorded the highest significant values of removal force at the end of storage during the second season compared with the others. On the contrary, but starting 15 days till the end of storage, only vines sprayed with $S_{2}$ were reached the significant. On the contrary, the lower berry removal force values were recorded by vines of control $\left(\mathrm{S}_{1}\right)$. This trend was cleared at picking date and during all storage periods. Our findings are in harmony with that of 
Chaves et al. (2007) and Amiri et al. (2009) they concluded that, Calcium foliar spray was reduced berry drops of "Thompson seedless" clusters. Moreover, application of calcium chloride improved "Thompson seedless" table grape postharvest quality regardless of application methods Claudia and Rafael (2010).

Regarding the interaction, it could be noticed that, vines irrigated at 50\% depletion of available water $\left(\mathrm{I}_{2}\right)$ in combined with calcium $\left(\mathrm{S}_{3}\right)$ as well as silicon $\left(\mathrm{S}_{2}\right)$ foliar sprays showed higher significant values of berry removal force at harvesting time but calcium sprays under $I_{1}$ and $I_{2}$ of irrigation levels reached the significant at the end of storage during the first season. As for the second season, vines irrigated at the $I_{2}$ level in combined with $S_{2}$ or $S_{3}$ cleared the higher significant berry removal force values starting picking date till the end of storage periods these combinations did not show any differences.

The lower values of this character were noticed with vines under unsprayed control $\left(\mathrm{S}_{1}\right)$ combined with all irrigation levels at harvest time and at the end of storage period during the two seasons. $\mathrm{I}_{3}$ of irrigation levels when combined with amino acids spray at picking date but, starting 15 days till the end of storage, vines of control $\left(S_{1}\right)$ under the same irrigation level showed the lower values.

These results are in harmony with that of Liang et al. (2007) and Marzouk and Kassem (2011) they concluded that, preharvest $\mathrm{Ca}$ sprays treatments on "Thompson seedless" grapevines was effective in increase berries firmness and decreased the percentage of unmarketable clusters after storage at ambient temperature for seven days.

\section{Berries shattering \%}

Data presented in Table (5) stated that, berries shatter percentages were increased as the irrigation water stress increased, where the lowest values were recorded with vines irrigated with $\mathrm{I}_{1}$ followed by that of $\mathrm{I}_{2}$, however the highest percentage was found with vines of $\mathrm{I}_{3}$ of irrigation level at harvest time and during cold storage periods in both season. Concerning foliar applications, data of the same Table cleared that, all spray treatments reduced berries shatter percent as compared to control especially calcium $\left(S_{3}\right)$ and silicon $\left(S_{2}\right)$ foliar sprays which showed significantly the lowest percentage, this was true at picking date and during cold storage in both seasons.

Regarding the interaction effect, data showed that, vines sprayed with $\mathrm{S}_{3}$ under irrigation with $I_{1}$ and $I_{2}$ levels showed the lower significant values of shattered berries at picking as well as at the end of cold storage (60 days) during two seasons, respectively. 
Table (5): Effect of irrigation levels and foliar spray with silicon, calcium and amino acids on berries shattering \% of "Thompson seedless" grapevines during cold storage at $1^{\circ} \mathrm{C}$ and RH 90-95\% in 2016 and 2017 seasons

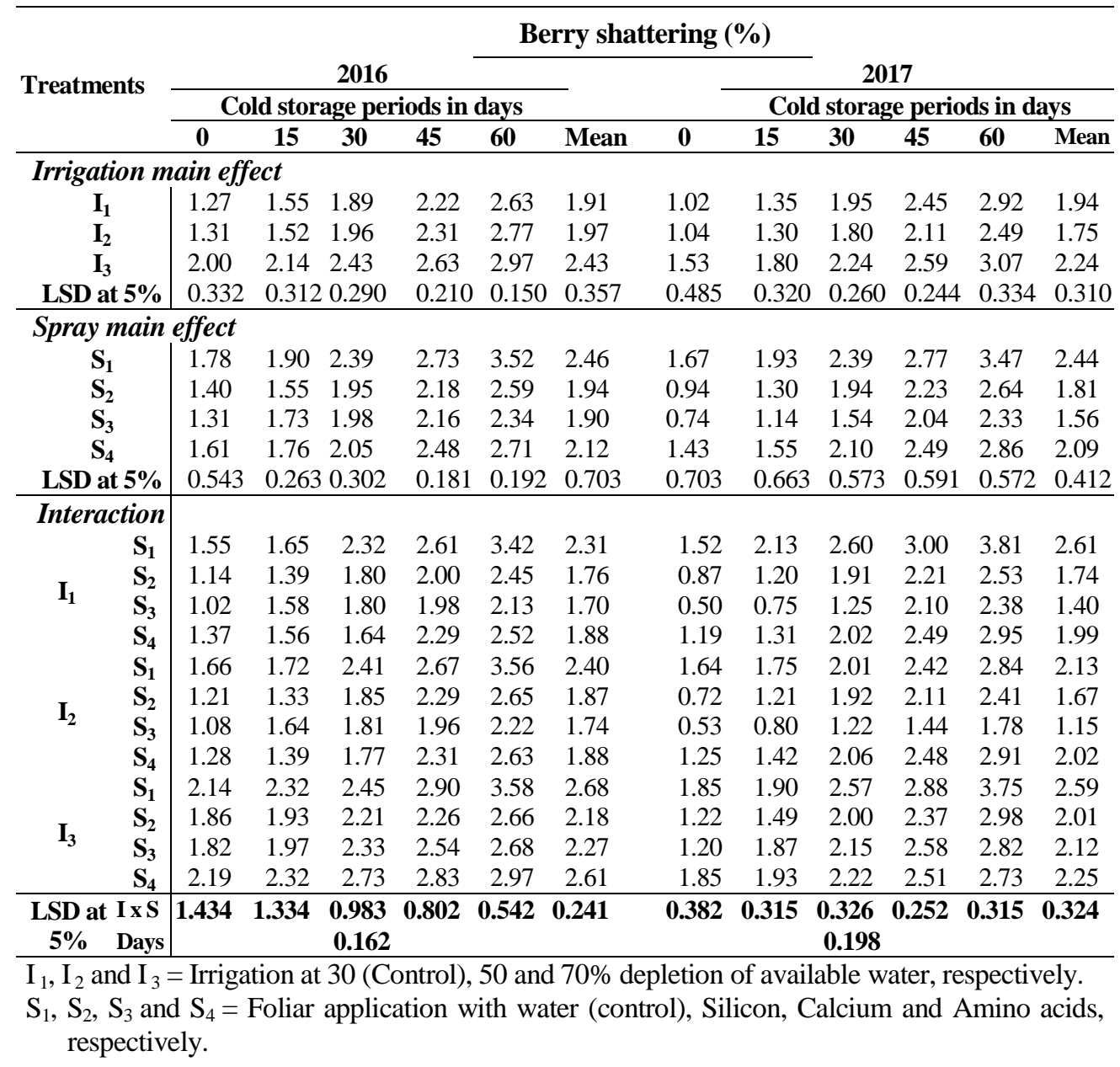

Clusters harvested from vines under the $\mathrm{I}_{2}$ irrigation level combined with $\mathrm{S}_{3}$ foliar spray showed the lowest significant values at the end of storage period compared with all other combination treatments in the two seasons. On the contrary, the higher percent of berry shatter was noticed with unsprayed control $\left(\mathrm{S}_{1}\right)$ as well as amino acids $\left(\mathrm{S}_{4}\right)$ when combined with $\mathrm{I}_{3}$ at harvesting time and throughout all storage period in both seasons. The results of berries shattering are in agreement with that of Smith et al. (2014) concluded that, calcium foliar spray on grapevines resulted in enhancing rachis, petiole measurements and reduced berries shattering at harvest. Also, Ramteke et al. (2017) concluded 
that, calcium nutrient increased cell wall thickness and decreased the formation of the abscission layer which leads to reducing shattering.

\section{Berries Decay \%}

Data illustrated in Table (6) showed that, vines under all irrigation levels ( $\mathrm{I}_{1}$ (control), $\mathrm{I}_{2}$ and $\mathrm{I}_{3}$ ) did not show any effect on berries decay percent at picking date and also during cold storage in both seasons of the study. On the contrary foliar spray treatments reduced the percentage of berries decay with calcium $\left(\mathrm{S}_{3}\right)$ and silicon $\left(\mathrm{S}_{2}\right)$ which showed the lowest value at picking date and at the end of storage time of both seasons, especially with calcium spray application which cleared the lower significant during cold storage compared with the others.

Table (6): Effect of irrigation levels and foliar spray with silicon, calcium and amino acids on berries decay \% of "Thompson seedless" grapevines during cold storage at $1^{0} \mathrm{C}$ and $\mathrm{RH} 90-95 \%$ in 2016 and 2017 seasons

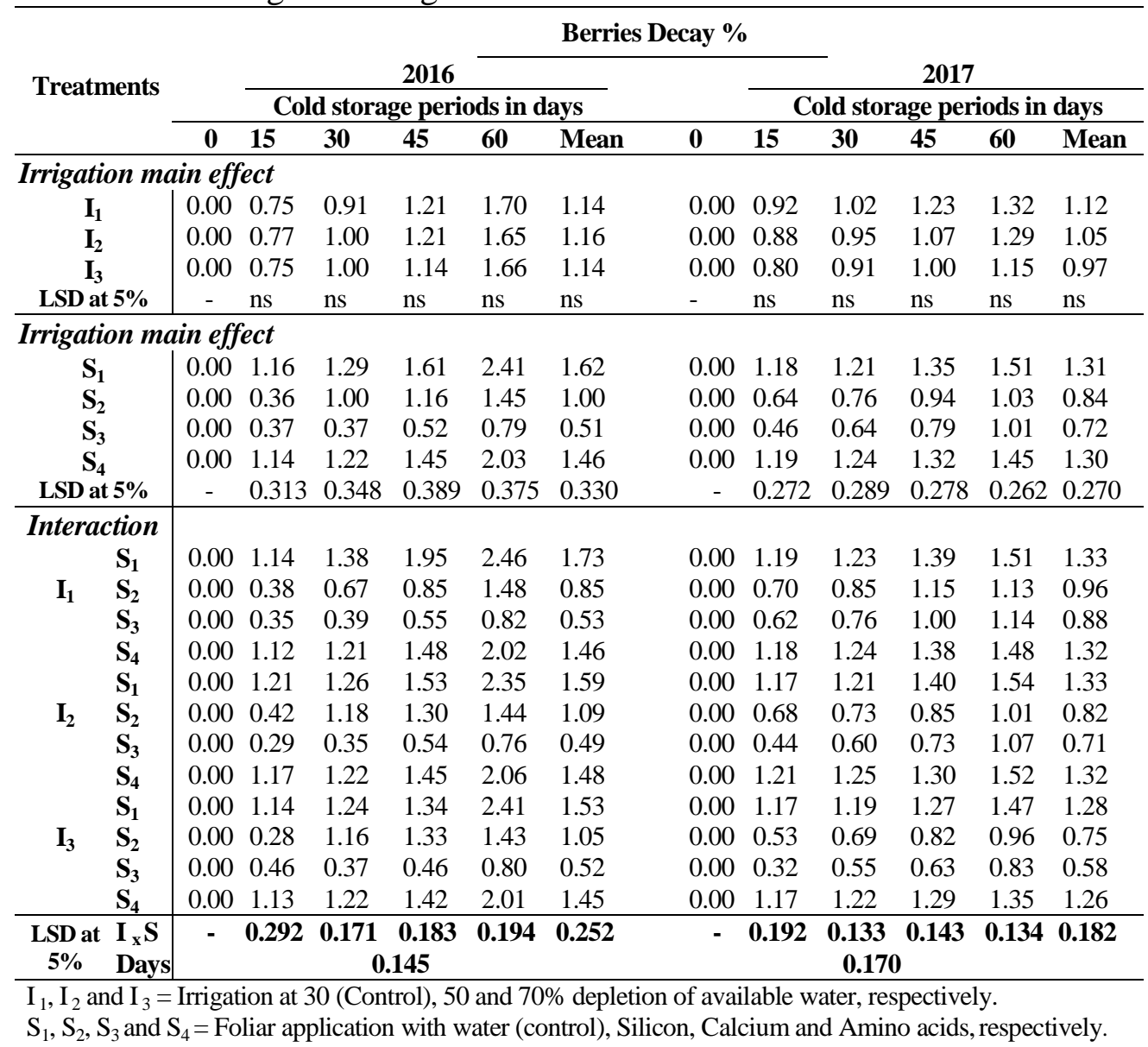


Concerning interaction data of the same Table (6) cleared that, foliar spray with $S_{2}$ as well as $S_{3}$ were very effective in reducing berries decay under all irrigation levels $\left(I_{1}, I_{2}\right.$ and $\left.I_{3}\right)$ at both harvesting date and during cold storage. This trend was true during both seasons, where $S_{3}$ was more effective in combination with $I_{2}$ in the first season and when combined with the third irrigation level $\left(\mathrm{I}_{3}\right)$ at picking date also during the storage period in the second season. These results are in agreement with the findings of Porro et al. (2010) and Cabanne and Doneche (2003) they explained that, at ripening, calcium was transported from berry flesh to its skin which enhanced berry resistance mitigates infection. Also, Porro et al. (2010) cleared that, high Ca levels in berries were registered in stressed vines, which indicates the important role of $\mathrm{Ca}$ in enhancing berry skin thickness. Moreover, Bhavya et al. (2011) reported that, foliar silicon supply on grapes showed great benefits as enhancing resistance against disease and drought. The positive effect of calcium and silicon on reducing decayed berries could be explained as the known role of calcium on cell wall, since $\mathrm{Ca}$ is involved in maintaining cell wall integrity by binding carboxyl groups of polygalacturonate chains, which are present in the middle lamella and primary cell wall, also binding of $\mathrm{Si}$ with cell-wall hemicelluloses which improved structural stability of fruits (Apaolaza, 2014).

\section{B. Berries chemical characters}

\section{1. $\quad \mathrm{SSC} \%$}

As shown in Figure (1) it could be noticed that, berries juice SSC\% slightly increased with the progress of storage time. Moreover, vines irrigated with $I_{2}$ recorded the higher percent as compared with control $\left(I_{1}\right)$ and $I_{3}$ at picking date and during the storage period of the two study seasons.

These results are in agreement with those findings by Khosroshahi et al. (2007) and Keller et al. (2008) reported that, deficit irrigation levels enhanced SSC\% of Cabernet Sauvignon berries under an Arid Climate. Also, Opazo et al. (2010) concluded that, moderate water stress significant increase in soluble solids.

Regarding foliar spray treatments at Figure (2) it cleared that, berries SSC\% of vines sprayed with amino acids $\left(\mathrm{S}_{4}\right)$ cleared the highest significant values at harvesting date and during all the storage periods $(15,30,45$ and 60 days of cold storage). The lowest values were obtained with $S_{1}$ (water spray) starting picking date till the end of storage. However, there were no significant differences between silicon $\left(S_{2}\right)$ and calcium $\left(S_{3}\right)$ sprays till the end of storage. This trend was true in both seasons.

Data established in Table (7) indicated that, SSC\% was increased with the progress of storage time. The combination of irrigation and foliar spray 


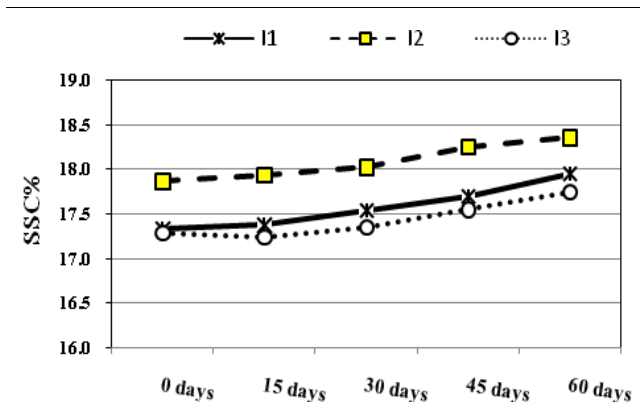

2016

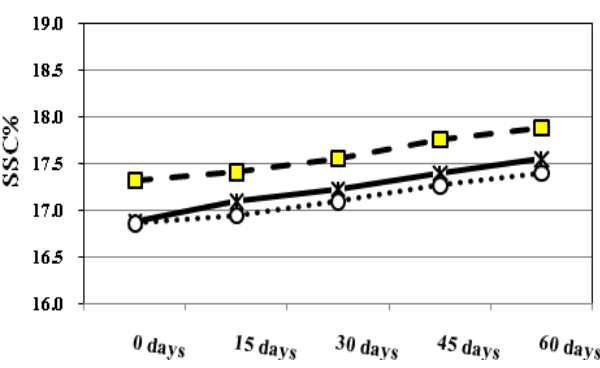

2017

Figure (1). Effect of water irrigation levels on berries SSC\% of "Thompson seedless" grape during cold storage at 2016 and 2017 seasons

$\mathrm{I}_{1}, \mathrm{I}_{2}$ and $\mathrm{I}_{3}=$ Irrigation at 30 (Control), 50 and $70 \%$ depletion of available water, respectively.

$\mathrm{S}_{1}, \mathrm{~S}_{2}, \mathrm{~S}_{3}$ and $\mathrm{S}_{4}=$ Foliar application with water (control), Silicon, Calcium and Amino acids, respectively.

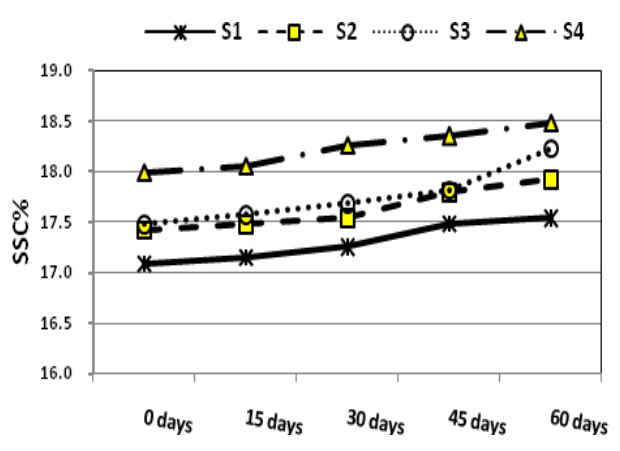

2016

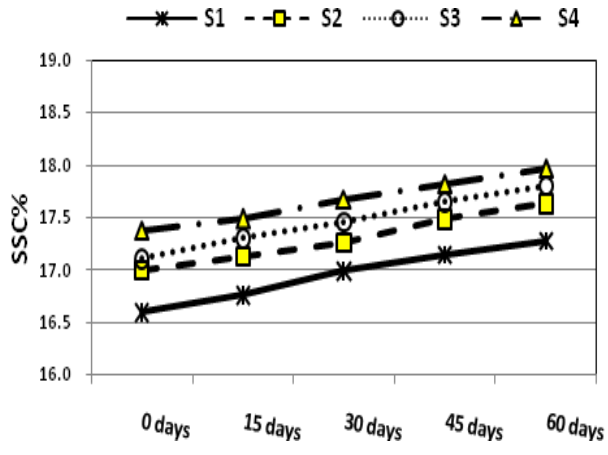

2017

Figure (2): Effect of foliar spray treatments on berries SSC\% of "Thompson seedless" grape during cold storage at 2016 and 2017 seasons

$\mathrm{I}_{1}, \mathrm{I}_{2}$ and $\mathrm{I}_{3}=$ Irrigation at 30 (Control), 50 and $70 \%$ depletion of available water, respectively.

$\mathrm{S}_{1}, \mathrm{~S}_{2}, \mathrm{~S}_{3}$ and $\mathrm{S}_{4}=$ Foliar application with water (control), Silicon, Calcium and Amino acids, respectively.

treatments were effective in enhancing berries juice SSC\%. The vines irrigated with $\mathrm{I}_{2}$ combined with amino acids sprays showed the highest significant $\mathrm{SSC} \%$ as compared with the other treatments at picking date as well as throughout all storage periods (from 15 till 60 days of cold storage). However, the combination between $S_{1}$ and both $I_{1}$ and $I_{3}$ showed the lowest values at picking date and during storage period without significant between them during the two seasons. $\mathrm{S}_{4}$ treatment recorded the highest values of $\mathrm{SSC} \%$ with all irrigation levels compared with the other treatments at the initial time and end 
Table (7): Effect of irrigation levels and foliar spray with silicon, calcium and amino acids on SSC\% of "Thompson seedless" grapevines during cold storage at $1^{\circ} \mathrm{C}$ and $\mathrm{RH} 90-95 \%$ in 2016 and 2017 seasons

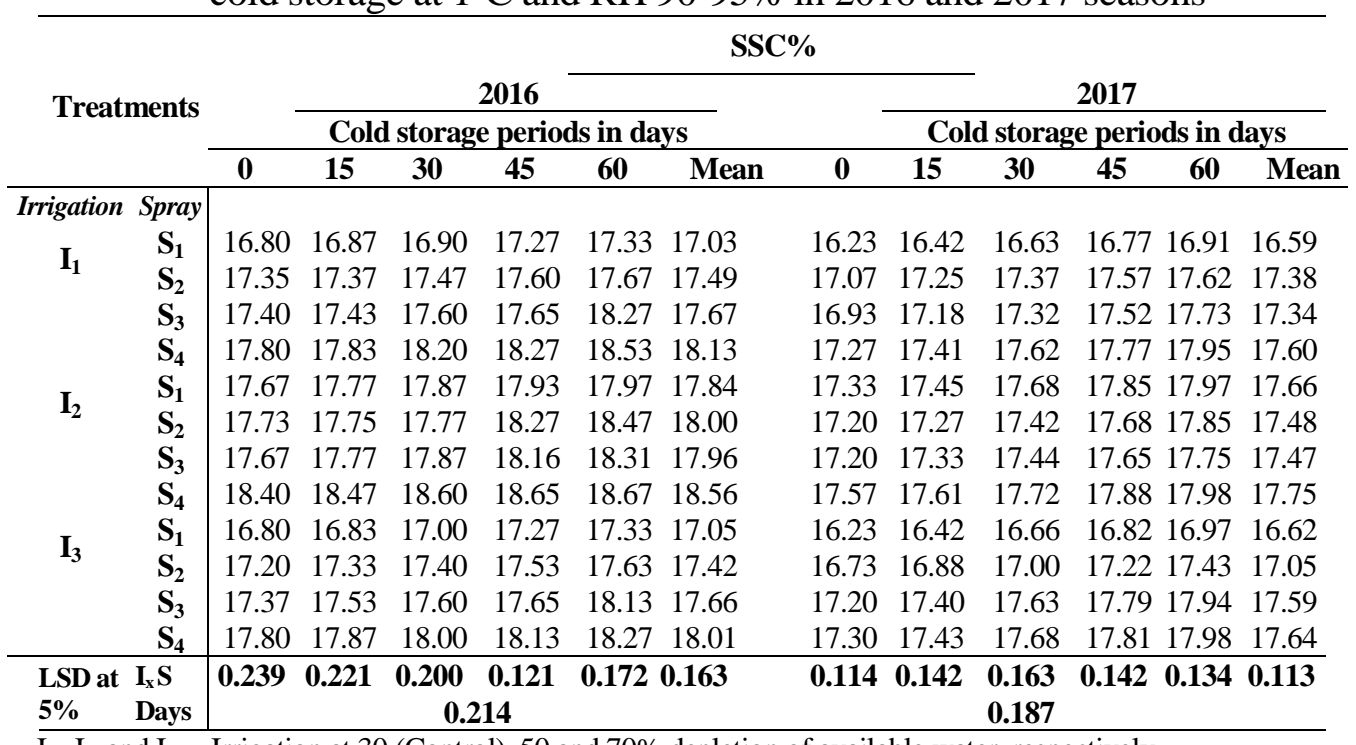

$\mathrm{I}_{1}, \mathrm{I}_{2}$ and $\mathrm{I}_{3}=$ Irrigation at 30 (Control), 50 and $70 \%$ depletion of available water, respectively.

$\mathrm{S}_{1}, \mathrm{~S}_{2}, \mathrm{~S}_{3}$ and $\mathrm{S}_{4}=$ Foliar application with water (control), Silicon, Calcium and Amino acids, respectively.

storage time in the two storage seasons. Our results are in harmony with those obtained by El-Ansari et al. (2005) on table grapes cv. 'Muscat of Alexandria' under different irrigation regimes and Al-Obeed (2011) on "Flame seedless" grape sprayed with preharvest calcium chloride and amino acids.

\section{Titratable acidity}

Berries juice titratable acidity illustrated in Figure (3) showed that, generally acidity of berries juice was slightly reduced with the progress of storage time in both seasons. Moreover, vines of irrigation control $\left(\mathrm{I}_{1}\right)$ showed the highest values of juice acidity as compared with other irrigation levels at the end of storage time in the two study seasons.

Foliar sprays of Figure (4) cleared that, amino acids $\left(\mathrm{S}_{4}\right)$ sprays recorded the highest significant values of juice acidity however, the lower values were noticed with calcium $\left(\mathrm{S}_{3}\right)$ sprays at harvesting date and during the cold storage periods, respectively in the first season. Amino acids, silicon and control treatments did not show any significant differences among them in the second season.

Data of interaction between irrigation and foliar spray treatments in Table (8) indicated that, titratable acidity was decreased with the increase of storage period in the two seasons. Vines sprayed with amino acids $\left(\mathrm{S}_{4}\right)$ which 


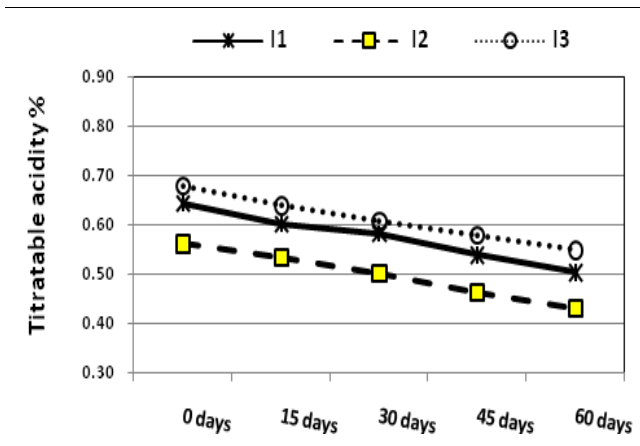

2016

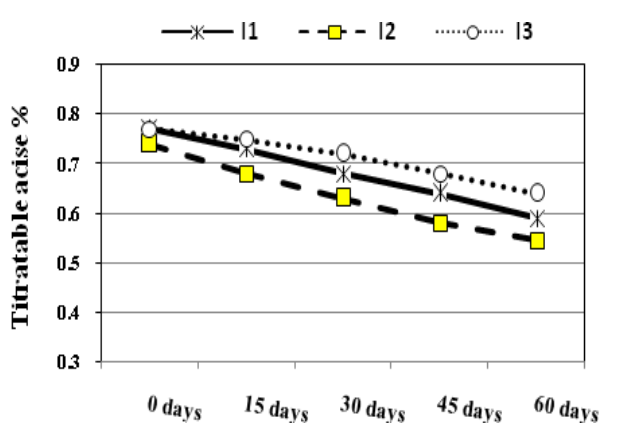

2017

Figure (3) Effect of water irrigation levels on berries titratable acidity\% of "Thompson seedless" grape during 2016 and 2017 seasons

$\mathrm{I}_{1}, \mathrm{I}_{2}$ and $\mathrm{I}_{3}=$ Irrigation at 30 (Control), 50 and $70 \%$ depletion of available water, respectively.

$\mathrm{S}_{1}, \mathrm{~S}_{2}, \mathrm{~S}_{3}$ and $\mathrm{S}_{4}=$ Foliar application with water (control), Silicon, Calcium and Amino acids, respectively.

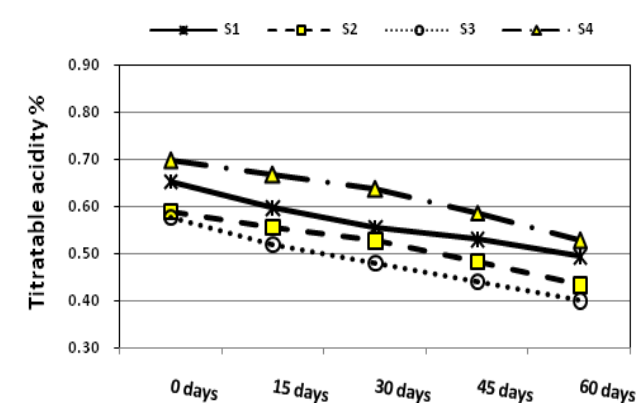

2016

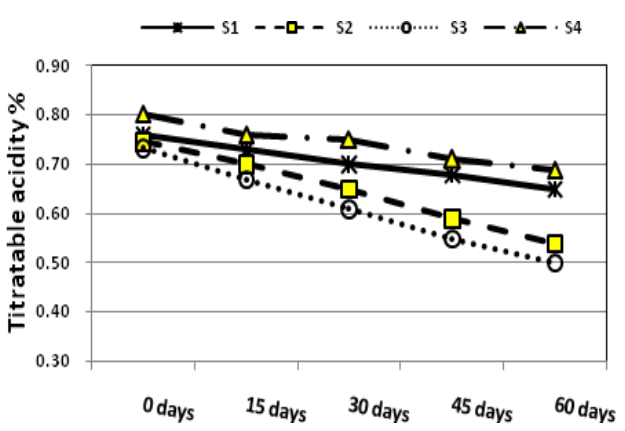

2017

Figure (4) Effect of foliar spray treatments on berries titratable acidity\% of "Thompson seedless" grape during 2016 and 2017 seasons

$\mathrm{I}_{1}, \mathrm{I}_{2}$ and $\mathrm{I}_{3}=$ Irrigation at 30 (Control), 50 and $70 \%$ depletion of available water, respectively.

$\mathrm{S}_{1}, \mathrm{~S}_{2}, \mathrm{~S}_{3}$ and $\mathrm{S}_{4}=$ Foliar application with water (control), Silicon, Calcium and Amino acids, respectively.

irrigated with $I_{1}$ and $I_{3}$ showed the higher significant berry juice acidity percentage starting picking date until the end of storage period in both seasons. The lowest percent was noticed in berries of vines sprayed with calcium $\left(\mathrm{S}_{3}\right)$ and silicon $\left(\mathrm{S}_{2}\right)$ combined with $\mathrm{I}_{2}$ at picking date and during storage till 60 days in the first season. But in the second one, there was no stable trend among all treatments. The similar findings were recorded by Ojeda et al. (2001) and Romero et al. (2015) and Khan et al. (2012) they summarized that, multiple 
Table (8): Effect of irrigation levels and foliar spray with silicon, calcium and amino acids on titratable acidity\% of "Thompson seedless" grapevines during cold storage at $1^{\circ} \mathrm{C}$ and RH 90-95\% in 2016 and 2017 seasons

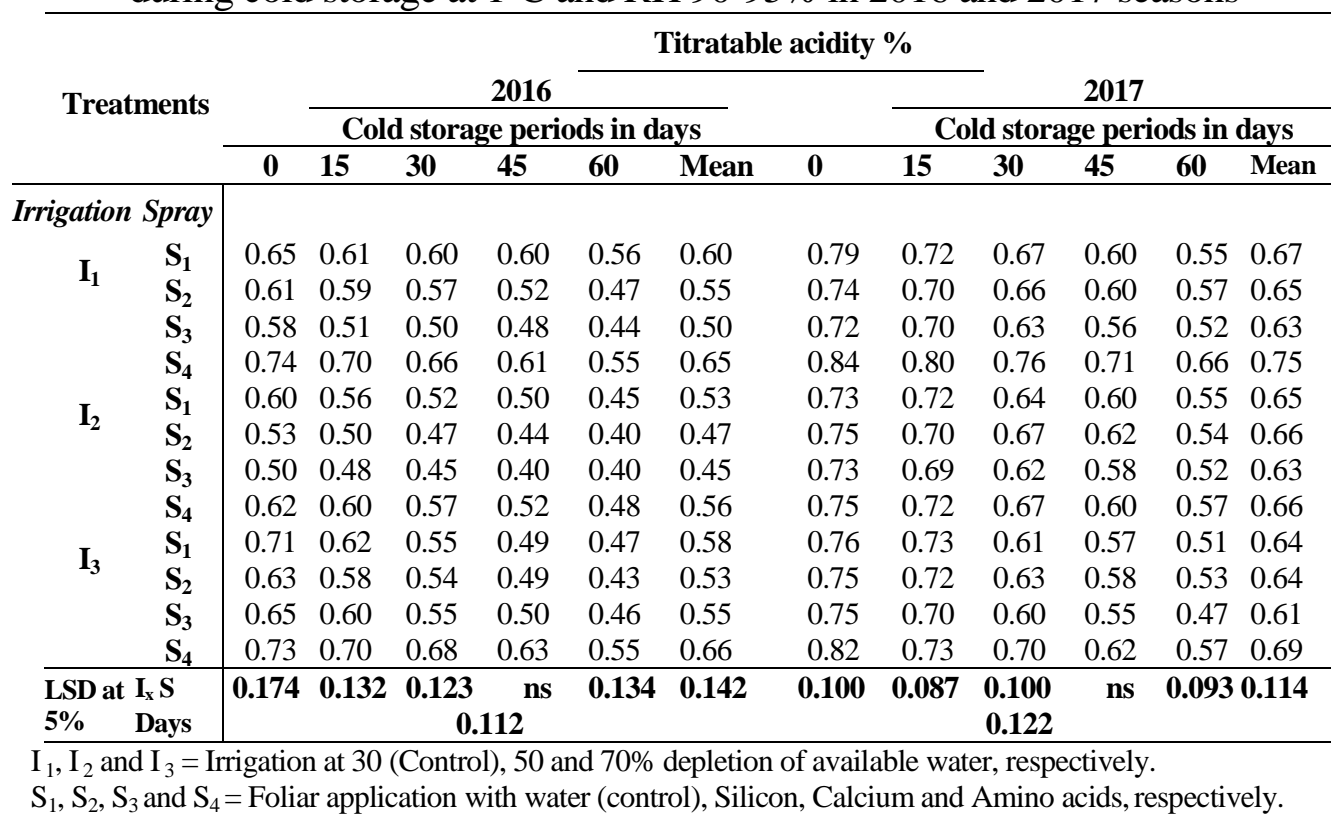

foliar applications of amino acids increased titratable acidity ratio (29\%) and $\mathrm{pH}$ of juice (3\%), of grape cv. 'Perlette'.

\section{SSC/Acid ratio (\%)}

Data presented in Table (9) cleared that, SSC/acid ratio affected by irrigation levels since, irrigation at $\mathrm{I}_{2}$ level showed the highest ratio at picking date as well as during all storage period in both seasons except in the second season, where there was no-showed a significant difference between $\mathrm{I}_{2}$ and $\mathrm{I}_{3}$ of irrigation levels at the end of storage period. On the other hand, the lowest ratio was noticed with $\mathrm{I}_{1}$ (control) at harvest date and during all storage times till 60 days.

As or foliar applications, calcium sprays $\left(\mathrm{S}_{3}\right)$ produced the higher significant of SSC/acid ratio at harvesting time and through all storage period in both seasons. However, the lower ratio was showed by unsprayed control $\left(\mathrm{S}_{1}\right)$ and $\mathrm{S}_{4}$ (amino acids spray) starting picking date and continually till 60 days of storage in both seasons with no significant effects between them in the first season and the initial time of storage in the second season. 
Table (9): Effect of irrigation levels and foliar spray with silicon, calcium and amino acids on SSC/acid ratio\% of "Thompson seedless" grapevines during cold storage at $1^{\circ} \mathrm{C}$ and $\mathrm{RH}$ 90-95\% in 2016 and 2017 seasons

\begin{tabular}{|c|c|c|c|c|c|c|c|c|c|c|c|c|}
\hline \multirow{4}{*}{ Treatments } & \multirow{2}{*}{\multicolumn{4}{|c|}{2016}} & \multicolumn{4}{|c|}{ SSC/Acid ratio\% } & \\
\hline & & & & & & \multirow[b]{3}{*}{ Mean } & \multirow[b]{3}{*}{$\mathbf{0}$} & \multirow{2}{*}{\multicolumn{3}{|c|}{$\begin{array}{c}2017 \\
\text { Cold storage peri }\end{array}$}} & & \\
\hline & \multicolumn{5}{|c|}{ Cold storage periods in days } & & & & & & ods in & days \\
\hline & $\mathbf{0}$ & 15 & 30 & 45 & 60 & & & 15 & 30 & 45 & 60 & Mean \\
\hline \multicolumn{13}{|c|}{ Irrigation main effect } \\
\hline $\mathrm{I}_{1}$ & 26.88 & 28.84 & 30.12 & 32.03 & 35.54 & 30.44 & 21.84 & 23.38 & 25.35 & 28.19 & 30.53 & 25.52 \\
\hline $\mathbf{I}_{2}$ & 31.76 & 33.53 & 35.88 & 39.25 & 42.44 & 36.21 & 23.41 & 24.61 & 27.02 & 29.61 & 32.82 & 27.13 \\
\hline $\mathrm{I}_{3}$ & 25.43 & 27.28 & 30.17 & 33.45 & 37.36 & 30.20 & 21.69 & 23.66 & 27.15 & 30.02 & 33.81 & 26.65 \\
\hline LSD at $5 \%$ & 1.363 & 1.282 & 1.254 & 1.282 & 1.315 & 1.163 & 1.213 & 1.272 & 1.361 & 1.372 & 1.273 & 0.724 \\
\hline \multicolumn{13}{|c|}{ Irrigation main effect } \\
\hline$S_{1}$ & 26.16 & 27.97 & 31.00 & 33.00 & 35.56 & 30.40 & 21.55 & 23.18 & 26.55 & 29.06 & 32.20 & 26.01 \\
\hline $\mathbf{S}_{2}$ & 29.54 & 31.41 & 33.32 & 36.83 & 41.36 & 34.05 & 22.77 & 24.25 & 26.42 & 29.15 & 32.26 & 26.59 \\
\hline $\mathbf{S}_{3}$ & 30.31 & 33.16 & 35.38 & 38.74 & 42.08 & 35.52 & 23.33 & 24.84 & 28.32 & 31.34 & 35.38 & 28.05 \\
\hline $\mathrm{S}_{4}$ & 25.84 & 27.09 & 28.69 & 31.28 & 35.11 & 29.28 & 21.63 & 23.31 & 24.89 & 27.70 & 29.95 & 25.19 \\
\hline LSD at $5 \%$ & 1.722 & 1.681 & 1.874 & 1.733 & 1.772 & 1.652 & 1.141 & 1.192 & 1.174 & 1.213 & 1.232 & 0.572 \\
\hline \multicolumn{13}{|l|}{ Interaction } \\
\hline \multirow{5}{*}{$\mathbf{I}_{1}$} & 25.85 & 27.66 & 28.17 & 28.78 & 30.95 & 28.20 & 20.54 & 22.81 & 24.82 & 27.95 & 30.75 & 24.91 \\
\hline & 28.44 & 29.44 & 30.65 & 33.85 & 37.60 & 31.69 & 23.07 & 24.64 & 26.32 & 29.28 & 30.91 & 26.57 \\
\hline & 30.00 & 34.18 & 35.20 & 36.77 & 41.52 & 35.20 & 23.51 & 24.54 & 27.49 & 31.29 & 34.10 & 27.69 \\
\hline & 24.05 & 25.47 & 27.58 & 29.95 & 33.69 & 27.80 & 20.56 & 21.76 & 23.18 & 25.03 & 27.20 & 23.35 \\
\hline & 29.45 & 31.73 & 34.37 & 35.86 & 39.93 & 33.92 & 23.74 & 24.24 & 27.63 & 29.75 & 32.67 & 27.25 \\
\hline \multirow{4}{*}{$\mathbf{I}_{2}$} & 33.45 & 35.50 & 37.81 & 41.52 & 46.18 & 38.46 & 22.93 & 24.67 & 26.00 & 28.52 & 33.06 & 26.65 \\
\hline & 35.34 & 37.02 & 39.71 & 45.40 & 45.78 & 40.26 & 23.56 & 25.12 & 28.13 & 30.43 & 34.13 & 27.82 \\
\hline & 29.68 & 30.78 & 32.63 & 35.87 & 38.90 & 33.26 & 23.43 & 24.46 & 26.45 & 29.80 & 31.54 & 26.82 \\
\hline & 23.66 & 25.12 & 30.91 & 35.24 & 36.87 & 29.49 & 20.54 & 22.49 & 27.31 & 29.51 & 33.27 & 25.89 \\
\hline \multirow{3}{*}{$\mathbf{I}_{\mathbf{3}}$} & 27.30 & 29.88 & 32.22 & 35.78 & 41.00 & 32.62 & 22.31 & 23.44 & 26.98 & 29.69 & 32.89 & 26.56 \\
\hline & 26.72 & 29.22 & 32.00 & 35.30 & 39.41 & 31.99 & 22.93 & 24.86 & 29.38 & 32.35 & 38.17 & 28.65 \\
\hline & 24.38 & 25.53 & 26.47 & 28.78 & 33.22 & 27.38 & 21.10 & 23.88 & 25.26 & 28.73 & 31.54 & 25.64 \\
\hline \multirow{2}{*}{$\begin{array}{c}\text { LSD at } \\
\mathbf{5 \%}\end{array}$} & 1.213 & 1.154 & 1.272 & 1.334 & 1.253 & 1.234 & 2.432 & \multirow{2}{*}{\multicolumn{2}{|c|}{$\begin{array}{ll}1.602 & 1.492 \\
1.312\end{array}$}} & 1.601 & 1.663 & 1.374 \\
\hline & & & 1.107 & & & & & & & & & \\
\hline
\end{tabular}

Concerning the interaction, data of the same Table (9) cleared that, there was a gradual increase in $\mathrm{SSC} /$ acid ratio with the progress of storage time. "Thompson seedless" vines which irrigated at $\mathrm{I}_{2}$ and sprayed with silicon $\left(\mathrm{S}_{2}\right)$ or calcium $\left(\mathrm{S}_{3}\right)$, showed the highest ratio during harvest and during the different storage periods $(15,30,45$ and 60 days) in the first season. By the second one, this trend was found with vines sprayed with calcium and unsprayed one which irrigated with $\mathrm{I}_{2}$ at harvest, whereas unsprayed $\left(\mathrm{S}_{1}\right)$ and sprayed with calcium $\left(\mathrm{S}_{3}\right)$ vines which were irrigated at $\mathrm{I}_{3}$ recorded the highest values of $\mathrm{SSC} /$ acid ratio at the end of storage period. In contrast, the lower values of SSC/acid ratio was found with both unsprayed vines and sprayed with silicon combined with irrigation at $I_{1}$ or $I_{3}$ at harvest time and at the end of storage times in the two study seasons. This could be understood according to the results of several researchers (Torrigiani et al., 2004 and El-Sayed, 2013) they found that, the 
deficit irrigation had a direct inhibiting effect on shoots growth which reflected on carbohydrate reserve to cluster and enhanced SSC versus acidity. However, in contrast, foliar spray with amino acids help vine shoots to mitigate water deficit stress (Khosroshahi et al., 2007).

\section{Cluster physical characters \\ 1. Cluster weight loss \%}

Regarding cluster weight loss during cold storage, Figures (5) and (6) showed that clusters harvested from vines of irrigation control $\left(\mathrm{I}_{1}\right)$ recorded the highest weight loss starting 15 days till the end of cold storage period (60 days). On the contrary, clusters which harvested from vines irrigated at $\mathrm{I}_{3}$ level showed the lowest significant percent of cluster weight losses in both seasons.

As for foliar spray treatments generally, vines sprayed with silicon, calcium and amino acids showed a significant reducing in weight loss of clusters during all storage periods (from 15 to 60 day) as compared to control. In this respect, calcium and amino acids spray recorded the lower weight loss during both seasons.

Interaction data in Table (10) showed that, cluster weight loss during cold storage was affected by all foliar spray treatments under all irrigation levels especially amino acids $\left(\mathrm{S}_{4}\right)$ sprayed when combined with $\mathrm{I}_{3}$ level of irrigation which showed significant decrease in weight loss as compared with other treatments after 15 days of cold storage in both seasons of the study.

However, at the end of the storage period (60 days), the clusters which harvested from vines sprayed with calcium $\left(\mathrm{S}_{3}\right)$ or amino acids $\left(\mathrm{S}_{4}\right)$ combined with $I_{1}$ showed the lowest weight loss percentages during the two seasons without significant differences among them. These results are in line with those of Khosroshahi et al. (2007) they summarized that, exogenously applied amino acids enhanced some fruit quality through changes in fruit skin thickness which reduced weight loss.

\section{Rachis browning index}

Data presented in Table (11) stated that, all irrigation levels had no significant effect on rachis browning index at harvest time in both seasons of the study. However, rachis browning increased with the incidence of storage time. The lowest degrees of rachis browning were noticed with clusters harvested from vines irrigated with $I_{1}$ starting 30 days till the end of storage in both season however; the highest rachis browning degree was obtained with clusters of vines irrigated with $\mathrm{I}_{3}$ in both seasons.

As for foliar applications, it could be noticed that, all spray treatments were effective in reducing the increase in rachis browning during cold storage 


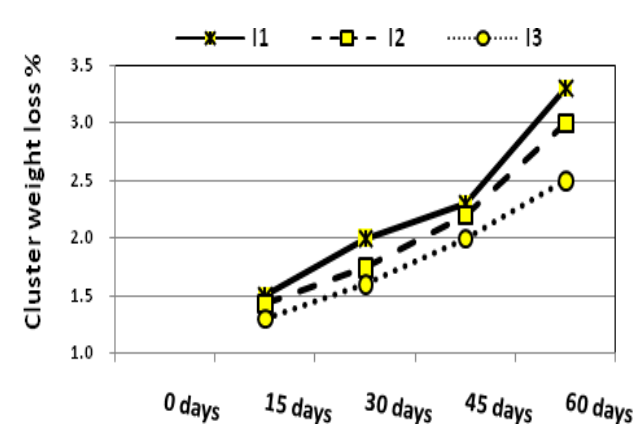

2016

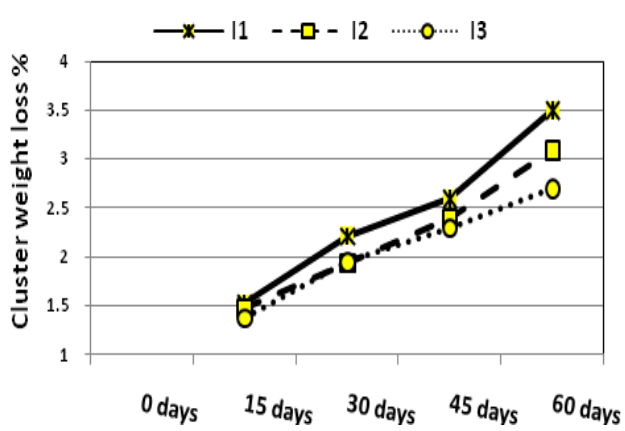

2017

Figure (5) Effect of water irrigation levels on Thompson seedless grape cluster weight loss\% during cold storage at 2016 and 2017 seasons

$\mathrm{I}_{1}, \mathrm{I}_{2}$ and $\mathrm{I}_{3}=$ Irrigation at 30 (Control), 50 and $70 \%$ depletion of available water, respectively.

$\mathrm{S}_{1}, \mathrm{~S}_{2}, \mathrm{~S}_{3}$ and $\mathrm{S}_{4}=$ Foliar application with water (control), Silicon, Calcium and Amino acids, respectively.

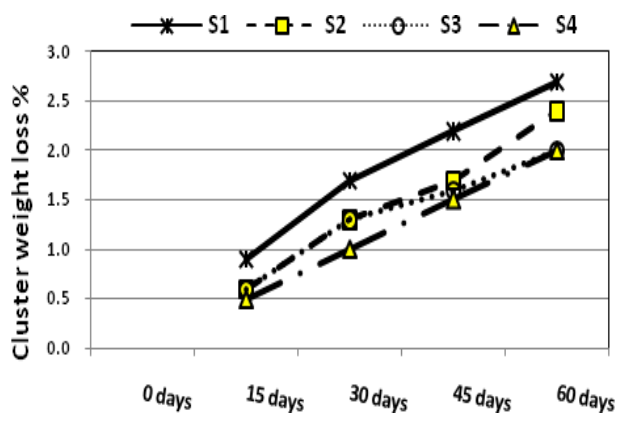

2016

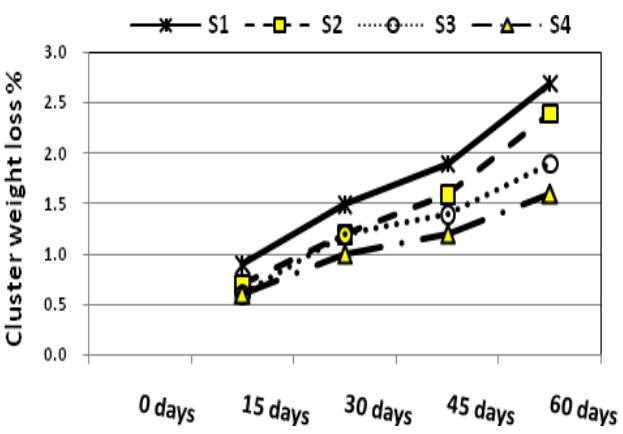

2017

Figure (6) Effect of foliar spray treatments on Thompson seedless grape cluster weight loss \% during cold storage at 2016 and 2017 seasons

$\mathrm{I}_{1}, \mathrm{I}_{2}$ and $\mathrm{I}_{3}=$ Irrigation at 30 (Control), 50 and $70 \%$ depletion of available water, respectively.

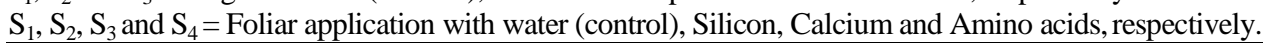

especially, amino acids $\left(\mathrm{S}_{4}\right)$ spray which showed the lowest significantly values. On the contrary, control $\left(S_{1}\right)$ showed the highest values till 60 days of storage in both seasons of study.

Concerning the interaction, data in the same Table (11) showed that, rachis browning index was increased with the progress of storage period under all treatments during the two seasons. "Thompson seedless" grapevines under all irrigation levels $\left(\mathrm{I}_{1}, \mathrm{I}_{2}\right.$ and $\left.\mathrm{I}_{3}\right)$ in combined with unsprayed control $\left(\mathrm{S}_{1}\right)$ cleared the highest significant values of rachis 
Table (10): Effect of irrigation levels and foliar spray with silicon, calcium and amino acids on cluster weight loss\% of "Thompson seedless" grapevines during cold storage at $1{ }^{\circ} \mathrm{C}$ and RH 90-95\% in 2016 and 2017 seasons

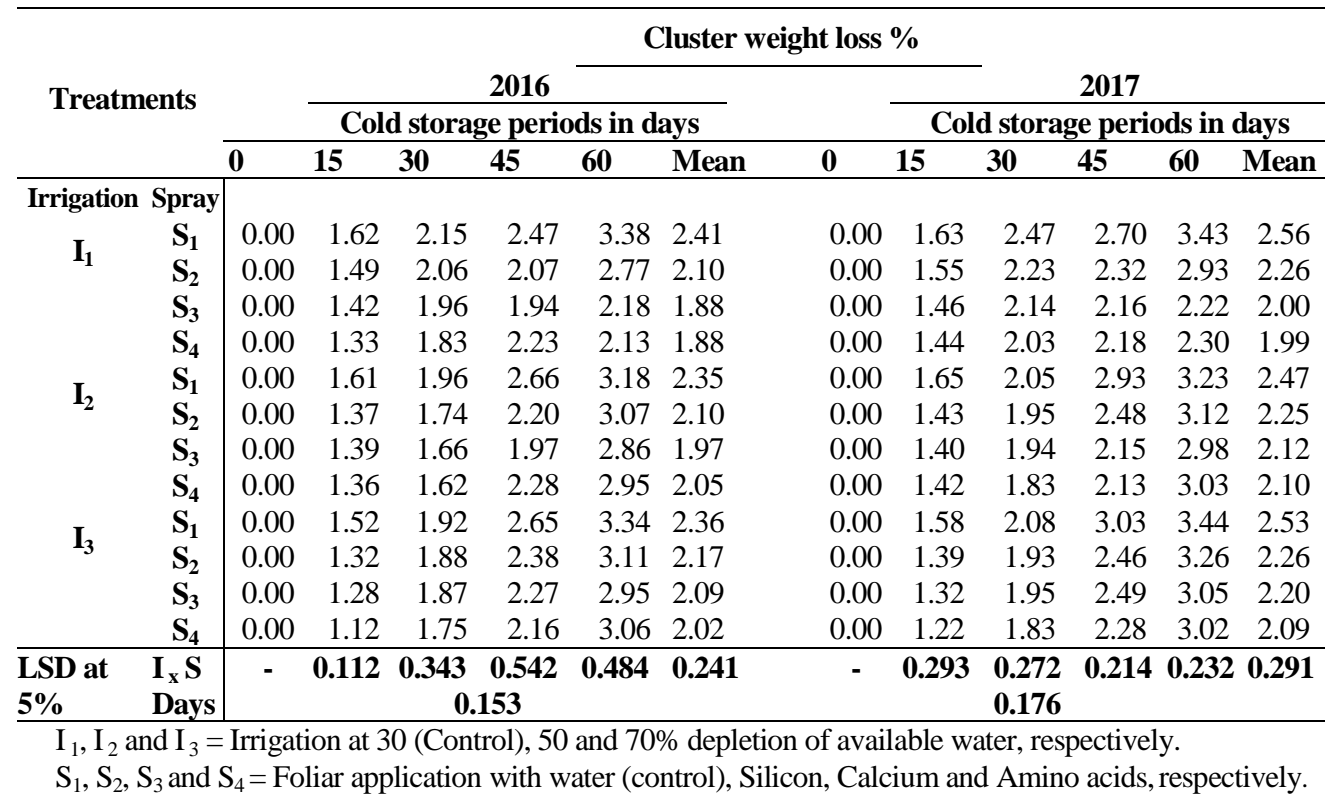

browning during storage period (from 15 to 60 days) in both seasons. The vines sprayed with amino acids $\left(S_{4}\right)$ under all irrigation levels $\left(I_{1}, I_{2}\right.$ and $\left.I_{3}\right)$ showed the lowest values starting 15 to 60 days of cold storage. The vines sprayed with the same application $S_{4}$ in combined with $\mathrm{I}_{1}$ showed the lowest values. on the contrary the highest values of rachis browning index were found with $S_{1}$ combined with $\mathrm{I}_{3}$ compared with all treatments during the two study seasons till the end of storage. These results could understand according to the findings of Crisisto et al. (2002) they reported that, there was high correlation between water losses from cluster and stem browning where, when water loss ranged between 0.5 to $2.1 \%$ of the initial cluster weight for 8 hour period at room temperature or even a few hours at high temperature before pre-cooling can cause severe drying and browning of cluster stems, so it could be reflected the browning of rachis during cold storage partially to water loss. Moreover, Wright et al. (2009) cleared that, rachis chlorophyll fluorescence is correlated to water loss from cluster and browning in both intact berries and rachis is certainly due to oxidation of phenolics through quinones to brown pigments by the action of polyphenol oxidase. 
Table (11): Effect of irrigation levels and foliar spray with silicon, calcium and amino acids on rachis shape index of "Thompson seedless" grapevines during cold storage at $1{ }^{\circ} \mathrm{C}$ and RH $90-95 \%$ in 2016 and 2017 seasons

\begin{tabular}{|c|c|c|c|c|c|c|c|c|c|c|c|c|}
\hline \multirow{4}{*}{ Treatments } & \multirow{2}{*}{\multicolumn{4}{|c|}{2016}} & \multicolumn{4}{|c|}{ Rachis browning index } & \\
\hline & & & & & & & \multirow{2}{*}{\multicolumn{6}{|c|}{$\begin{array}{c}2017 \\
\text { Cold storage periods in days }\end{array}$}} \\
\hline & \multicolumn{5}{|c|}{ Cold storage periods in days } & & & & & & & \\
\hline & $\mathbf{0}$ & 15 & 30 & 45 & 60 & Mean & $\mathbf{0}$ & 15 & 30 & 45 & 60 & Mean \\
\hline \multicolumn{13}{|c|}{ Irrigation main effect } \\
\hline$I_{1}$ & 1.00 & 1.40 & 1.73 & 2.01 & 2.25 & 1.68 & 1.00 & 1.38 & 1.80 & 2.15 & 2.41 & 1.75 \\
\hline $\mathbf{I}_{2}$ & 1.00 & 1.43 & 1.86 & 2.14 & 2.40 & 1.77 & 1.00 & 1.44 & 1.87 & 2.18 & 2.43 & 1.78 \\
\hline$I_{3}$ & 1.00 & 1.50 & 2.01 & 2.26 & 2.53 & 1.86 & 1.00 & 1.52 & 2.09 & 2.40 & 2.76 & 1.95 \\
\hline LSD at $5 \%$ & ns & ns & 0.198 & 0.233 & 0.219 & 0.140 & ns & 0.122 & 0.140 & 0.172 & 0.177 & 0.180 \\
\hline \multicolumn{13}{|c|}{ Spray main effect } \\
\hline$S_{1}$ & 1.00 & 1.80 & 2.43 & 2.95 & 3.43 & 2.32 & 1.00 & 1.77 & 2.62 & 3.15 & 3.63 & 2.43 \\
\hline $\mathbf{S}_{2}$ & 1.00 & 1.37 & 1.77 & 1.93 & 2.10 & 1.63 & 1.00 & 1.40 & 1.82 & 2.03 & 2.32 & 1.71 \\
\hline $\mathrm{S}_{3}$ & 1.00 & 1.37 & 1.80 & 2.00 & 2.13 & 1.66 & 1.00 & 1.37 & 1.73 & 2.00 & 2.27 & 1.67 \\
\hline $\mathbf{S}_{4}$ & 1.00 & 1.23 & 1.47 & 1.67 & 1.90 & 1.45 & 1.00 & 1.25 & 1.51 & 1.78 & 1.92 & 1.49 \\
\hline LSD at 5\% & Ns & 0.121 & 0.129 & 0.137 & 0.140 & 0.157 & Ns & 0.140 & 0.150 & 0.157 & 0.166 & 0.169 \\
\hline \multicolumn{13}{|l|}{ Interaction } \\
\hline \multirow{5}{*}{$\begin{array}{lll} & & \mathbf{S} \\
& & \mathbf{S} \\
\mathbf{I}_{1} & \mathrm{~S} \\
& & \mathbf{S} \\
& & \mathbf{S}\end{array}$} & 1.00 & 1.70 & 2.40 & 2.95 & 3.30 & 2.27 & 1.00 & 1.60 & 2.70 & 3.00 & 3.50 & 2.36 \\
\hline & 1.00 & 1.30 & 1.60 & 1.80 & 2.00 & 1.54 & 1.00 & 1.40 & 1.70 & 2.05 & 2.30 & 1.69 \\
\hline & 1.00 & 1.40 & 1.50 & 1.75 & 1.95 & 1.52 & 1.00 & 1.30 & 1.45 & 1.85 & 2.05 & 1.53 \\
\hline & 1.00 & 1.20 & 1.40 & 1.55 & 1.75 & 1.38 & 1.00 & 1.22 & 1.35 & 1.70 & 1.80 & 1.41 \\
\hline & 1.00 & 1.80 & 2.30 & 2.90 & 3.50 & 2.30 & 1.00 & 1.90 & 2.40 & 3.05 & 3.60 & 2.39 \\
\hline \multirow{3}{*}{$\begin{array}{l}S_{3} \\
S_{4}\end{array}$} & 1.00 & 1.40 & 1.80 & 2.00 & 2.10 & 1.66 & 1.00 & 1.30 & 1.75 & 1.85 & 2.05 & 1.59 \\
\hline & 1.00 & 1.30 & 1.90 & 1.95 & 2.05 & 1.64 & 1.00 & 1.30 & 1.80 & 2.05 & 2.20 & 1.67 \\
\hline & 1.00 & 1.20 & 1.45 & 1.70 & 1.95 & 1.46 & 1.00 & 1.24 & 1.54 & 1.75 & 1.85 & 1.48 \\
\hline \multirow{4}{*}{$\mathbf{I}_{3}$} & 1.00 & 1.90 & 2.60 & 3.00 & 3.50 & 2.40 & 1.00 & 1.80 & 2.75 & 3.40 & 3.80 & 2.55 \\
\hline & 1.00 & 1.40 & 1.90 & 2.00 & 2.20 & 1.70 & 1.00 & 1.50 & 2.00 & 2.20 & 2.60 & 1.86 \\
\hline & 1.00 & 1.40 & 2.00 & 2.30 & 2.40 & 1.82 & 1.00 & 1.50 & 1.95 & 2.10 & 2.55 & 1.82 \\
\hline & 1.00 & 1.30 & 1.55 & 1.75 & 2.00 & 1.52 & 1.00 & 1.28 & 1.65 & 1.90 & 2.10 & 1.59 \\
\hline \multirow{2}{*}{$\begin{array}{l}\text { LSD at I X S } \\
\text { 5\% Days }\end{array}$} & ns & 0.331 & $\begin{array}{l}0.384 \\
\end{array}$ & 0.352 & 0.364 & 0.376 & ns & 0.371 & 0.377 & 0.348 & 0.340 & 0.338 \\
\hline & & & 0.165 & & & & & & 0.178 & & & \\
\hline
\end{tabular}

\section{Marketable clusters (\%)}

Data presented in Table (12) demonstrated that, all irrigation levels $\left(\mathrm{I}_{1}, \mathrm{I}_{2}\right.$ and $\mathrm{I}_{3}$ ) did not affect the percentage of marketable clusters after 60 days of cold storage in both seasons. Foliar sprays treatments were effective in enhancing these percent. Calcium $\left(S_{3}\right)$ and amino acids $\left(S_{4}\right)$ applications showed the higher percent of "Thompson seedless" grape marketable clusters without differences between them during the two seasons.

Regarding interaction, it could be noticed that, vines at $I_{1}$ and $I_{2}$ irrigation treatments in combined with $S_{3}$ or $S_{4}$ showed the highest significant percent of marketable clusters at the end of storage time compared with all treatments during the two seasons of this study. On the other hand, the lower percentages 
Table (12): Effect of irrigation levels and foliar spray with silicon, calcium and amino acids on marketable clusters\% and cluster total quality of Thompson seedless grape after 60 days of cold storage at $1^{\circ} \mathrm{C}$ and RH 90-95\% and irrigation water use efficiency (IWUE) in 2016 and 2017 seasons

\begin{tabular}{|c|c|c|c|c|c|c|c|}
\hline \multirow{2}{*}{\multicolumn{2}{|c|}{ Treatments }} & \multicolumn{3}{|c|}{$\begin{array}{c}\text { Marketable clusters } \\
(\%)\end{array}$} & \multicolumn{3}{|c|}{$\begin{array}{c}\text { Cluster total qualities index } \\
\text { (CTQI) }\end{array}$} \\
\hline & & 2016 & 2017 & Mean & 2016 & 2017 & Mean \\
\hline \multicolumn{8}{|c|}{ Irrigation main effect } \\
\hline & & 98.64 & 97.89 & 98.27 & 0.955 & 0.975 & 0.97 \\
\hline & & 98.58 & 97.81 & 98.20 & 0.973 & 0.987 & 0.98 \\
\hline & & 98.53 & 97.66 & 98.10 & 0.996 & 0.994 & 1.00 \\
\hline LSI & & ns & ns & ns & ns & ns & ns \\
\hline \multicolumn{8}{|c|}{ Spray main effect } \\
\hline & & 98.31 & 97.68 & 98.00 & 0.904 & 0.900 & 0.90 \\
\hline & & 98.56 & 97.56 & 98.06 & 0.968 & 0.941 & 0.95 \\
\hline & & 98.72 & 98.22 & 98.47 & 1.000 & 0.999 & 1.00 \\
\hline & & 98.76 & 98.56 & 98.66 & 0.934 & 0.939 & 0.94 \\
\hline LSI & & 0.282 & 0.263 & 0.245 & 0.031 & 0.044 & 0.521 \\
\hline \multicolumn{8}{|c|}{ Interaction } \\
\hline \multirow{5}{*}{$\mathbf{I}_{1}$} & $\mathbf{S}_{1}$ & 98.25 & 97.59 & 97.92 & 0.852 & 0.866 & 0.86 \\
\hline & $\mathbf{S}_{2}$ & 98.61 & 97.71 & 98.16 & 0.930 & 0.899 & 0.91 \\
\hline & $\mathbf{S}_{3}$ & 98.83 & 98.38 & 98.61 & 0.955 & 0.967 & 0.96 \\
\hline & $\mathbf{S}_{4}$ & 98.90 & 98.30 & 98.60 & 0.898 & 0.912 & 0.91 \\
\hline & $S_{1}$ & 98.31 & 97.31 & 97.81 & 0.879 & 0.871 & 0.88 \\
\hline \multirow[t]{4}{*}{$\mathbf{I}_{2}$} & $\mathbf{S}_{2}$ & 98.58 & 97.68 & 98.13 & 0.942 & 0.923 & 0.93 \\
\hline & $\mathbf{S}_{3}$ & 98.74 & 98.24 & 98.49 & 0.976 & 0.977 & 0.98 \\
\hline & $\mathrm{S}_{4}$ & 98.71 & 98.21 & 98.46 & 0.900 & 0.922 & 0.91 \\
\hline & $S_{1}$ & 98.31 & 97.41 & 97.86 & 0.909 & 0.893 & 0.90 \\
\hline \multirow[t]{3}{*}{$\mathbf{I}_{3}$} & $S_{2}$ & 98.53 & 97.73 & 98.13 & 0.954 & 0.932 & 0.94 \\
\hline & $\mathbf{S}_{3}$ & 98.59 & 97.69 & 98.14 & 0.987 & 0.977 & 0.98 \\
\hline & $\mathbf{S}_{4}$ & 98.68 & 97.87 & 98.28 & 0.932 & 0.912 & 0.92 \\
\hline \multicolumn{2}{|c|}{ LSD at 5\% } & 0.077 & 0.054 & 0.089 & 0.094 & 0.086 & 0.112 \\
\hline
\end{tabular}

$\mathrm{I}_{1}, \mathrm{I}_{2}$ and $\mathrm{I}_{3}=$ Irrigation at 30 (Control), 50 and $70 \%$ depletion of available water, respectively.

$\mathrm{S}_{1}, \mathrm{~S}_{2}, \mathrm{~S}_{3}$ and $\mathrm{S}_{4}=$ Foliar application with water (control), Silicon, Calcium and Amino acids, respectively.

were cleared by unsprayed control $\left(S_{1}\right)$ under all irrigation levels in both seasons. These results are in parallel with that of Claudia and Rafael (2010) they concluded that, calcium application as a foliar spray and soil drench were more effective to achieving different quality parameter as berries large, turgent, dry matter and cells size. Also, enhanced berry firmness.

\section{Cluster total qualities index (CTQI)}

Data of Table (12) cleared that, the different irrigation levels used in this study had no effect on CTQI in both seasons. However, foliar-applications, especially calcium $\left(\mathrm{S}_{3}\right)$ and amino acids $\left(\mathrm{S}_{4}\right)$ sprays were more effective in this respect, where it reached the higher value of this index as compared with the 
water spray $\left(\mathrm{S}_{1}\right)$ treatment during the two seasons of this study. Moreover, a combination of $S_{3}$, as well as $S_{4}$ with all irrigation levels especially $I_{1}$ and $I_{2}$, showed the highest values during all study seasons. However, $\mathrm{S}_{1}$ spray combined with all irrigation levels produced the lower values of CTQI. These results are in line with that of Ahmed et al. (2011) and Khan et al. (2012) they summarized that, multiple foliar applications of amino acids was very effective to improve berry physical and chemical quality characteristics of 'Perlette' grapes including rachis length by $13.5 \%$, berry weight by $14.78 \%$ and berry size by $7.33 \%$ moreover, it reduced berry drop by $10.6 \%$ as compared with control.

Conclusively, from these results, it could be concluded that, the moderate water irrigation (50\% depletion of soil available water) could be adopted in "Thompson seedless" vineyards grown in clay soil conditions, especially when combined with calcium or amino acids foliar spray when shoots recorded 15-20 $\mathrm{cm}$ in length, after fruit set and continues every two weeks till veraison stage which enhanced different clusters and berries physical and chemical quality characters at harvest date and during cold storage. Moreover, it raised marketable clusters percent without any defects on clusters and berries quality after 60 days of cold storage.

\section{REFERENCES}

A.O.A.C. (1990). Association of Official Agriculture Chemists. Official methods of analysis, $15^{\text {th }}$ Ed. Washington D.C., USA.

Abdel-Mawgoud, A.M.R., A.M. El-Bassiouny, A. Ghoname and S.D. AbouHussein (2011). Foliar Application of Amino Acids and Micronutrients Enhance Performance ofGreen Bean Crop under Newly Reclaimed Land Conditions. Australian Journal of Basic and Applied Sciences, 5(6): 51-55.

Ahmed, F.F.; A.I. Asmaa, A. E.M. Mansour, E.A. Shaaban, and M.S. ElShammaa (2011). Response of Thompson Seedless Grapevines to Application of Some Amino Acids Enriched with Nutrients as Well as Organic and Biofertilization. Research Journal of Agriculture and Biological Sciences, 7(2): 282-286

Al-Obeed, R.S. (2011). Enhancing the shelf life and storage ability of "Flame seedless" grapevine by agrochemicals preharvest foliar applications. Middle-East Journal of Scientific Research, 8(2): 319-327.

Al-Qurashi, A.D. and M.A. Awad (2015). Effect of pre-harvest calcium chloride and ethanol spray on quality of ' El-Bayadi' table grapes during storage. Vitis J Grapevine Resear, 52: 61. 
Amiri, E. M.; E, Fallahi and G, Safari (2009). Effects of Preharvest Calcium Sprays on Yield, Quality and Mineral Nutrient Concentrations of 'Asgari' Table Grape. International Journal of Fruit Science, 9 (3):294-304

Apaolaza, L. H. (2014). Can silicon partially alleviate micronutrient deficiency in plants? a review. Planta, 240(3):447-58

Bhavya, H. K.; V. G. Nache, S. Jaganath, K. N. Sreenivas and N. B. Prakash (2010). Effect of foliar silicic acid and boron acid in Bangalore blue grapes. University of Agricultural Sciences, A review, p.78.

Bhavya, H. K.; V. N. gowda, S. Jaganath, K. N. Sreenivas and N. B. Prakash (2011). Effect of foliar silicic acid and boron acid in Bangalore blue grapes. Proceedings of The $5^{\text {th }}$ International Conference on Silicon in Agriculture, September 13-18, 2011 Beijing, China

Cabanne, C. and B. Doneche (2003). Calcium accumulation and redistribution during the development of grape berry. Vitis, 42 (1):19-21

Chaves, M. M.; T. P. Santos, C. R. Souza, M. F. Ortun, M. L. Rodrigues and J. P. Maroco (2007). Deficit irrigation in grapevine improves water-use efficiency while controlling vigour and production quality. Ann Appl. Biol., 150: 237-252.

Claudia, B. and R. Rafael (2010). Effects of foliar and soil calcium application on yield and quality of table grape cv. "Thompson seedless". Journal of Plant Nutrition, 33 : (3) 299 -314

Crisisto, C. H.; D. Garner and G. Crisosto (2002). Carbon dioxide-enriched atmospheres during cold storage limits losses from Botrytis but accelerate rachis browning of Red Globe table grapes. Postharvest Biol. Tec., 26:181189.

Davis, D. D. (1982). Physiological aspects of protein turn over. Encycl. Plant Physiol. New Series, HA (Nucleic acids and proteins: Structure Biochemistry And Physiology Of Proteins. Ed. Boulter D, Partheir B. Spring Verlag. Berlin, Heidelberg and New York., 90-288.

Dhekney, S. A. (2016). Encyclopedia Of Food And Health. Academic Press, Oxfor.pp.261-265.

El-Abbasy, U. K. (2006). Extending marketing window of Thompson seedless grapes by synthetic cytokinin and Naphthalene acetic acid preharvest spray treatments and cold storage. J. Agric. Res. Tanta Univ., 32(3):662-674

El-Ansari, D. O.; O. Oakayama, K. Hirano and G. Okamoto (2005). Response of Muscat of Alexandria table grapes to post-veraison regulated deficit irrigation in Japan. Vitis, 44 (1):5-9

El-Sayed, M. E. A. (2013). Improving Fruit Quality and Marketing of "Crimson Seedless" Grape Using Some Preharvest Treatments. Journal of Horticultural Science \& Ornamental Plants, 5 (3):218-226. 
Jackson M. L. (1973). Soil Chemical Analysis Prentice Hall of India Private, LTD, New Delhi.

Javed, M. S.; M. A. Randhawa, M. S. Butt and H. Nawaz (2015). Effect of calcium lactate and modified atmosphere storage on biochemical characteristics of guava fruit. J. Food Process Preserv.

Jiao-jing, L. I. ; L. I. Shao-hang, X.U. Pei-lei, W. Xiu-juan and B.A. Ji-gang (2009). Effects of Exogenous Silicon on the Activities of Antioxidant Enzymes and Lipid Peroxidation in Chilling-Stressed Cucumber Leaves. Agricultural Sciences in China, 8:(9) 1075-1086.

Keller, M.; R. P. Smithyman and L. J. Mills (2008). Interactive Effects of Deficit Irrigation and Crop Loadon Cabernet Sauvignon in an Arid Climate. Am. J. Enol. Vitic, 59(3):221-234.

Khan, A. S.; B. Ahmad, M. J. Jaskani, R. Ahmad and A. U. Malik (2012). Foliar application of mixture of amino acids and seaweed (Ascophylum nodosum) extract improve growth and physico-chemical properties of grapes. International Journal of Agriculture and Biology, 14: 383-388

Khosroshahi, M. R. Z.; M. Esna-Ashari and A. Ershadi (2007). Effect of exogenous putrescine on postharvest life of strawberry (Fragaria ananassa Duch.) fruit, cultivar Selva. Scientia Horticulturae, 114:27-32.

Klute, A. (1986). Water Retention: Laboratory Methods. In: A. Koute (ed.), Methods of soil Analysis, Part 1.2nd ed. Agron. Monogr. 9, ASA, Madison, W1 U.S.A., pp. 635-660.

Kluter, R.A.; D. T. Nattress, C. P. Dunne and R. D. Popper (2006). Shelf life Evaluation of Bartlett Pears in Retort Pouches. Journal of Food Science, 6: 1297-1302.

Liang, Y.; W. Sun, Y. G. Zhu and P. Christie (2007). Mechanisms of siliconmediated alleviation of abiotic stresses in higher plants. Environmental Pollution: A review 147 (7): 422-428

Martínez-de-Toda, F. and P. Balda (2013). Delaying berry ripening through manipulating leaf area to fruit ratio. Vitis , 52 (4):171-176.

Martínez-Romero, D.; D. Valero, M. Serrano and F. Riquelme (1999). Effects of post-harvest putrescine and calcium treatments on reducing mechanical damage and polyamines and ABA level during lemon storage. Journal of the Science of Food and Agriculture , 79:1589-1595.

Marzouk, H. A. and H. A. Kassem (2011). Improving yield, quality, and shelf life of Thompson seedless grapevine by preharvest foliar applications. Postharvest Biology and Technology, 130(2):425-430.

Maughan, T.; B. Brent, L. N. Allen, D. Dan and C. Grant (2017). "Grape Irrigation" All Current Publications. Paper 1768. https:// digitalcommons .usu.edu/extension_curall/1768. 
Meena, V.D.; M. L. Dotaniya , V. S. Coumar, A. S. Kundu and A. S. Rao (2014). A Case for Silicon Fertilization to Improve Crop Yields in Tropical Soils. Proc. Natl. Acad. Sci., India, Sect. Biol. Sci., 84(3):505-518

Meunier, M.; S. Rogiers, G. Gurr and R. Siret (2011). Grapevine vegetative growth and reproductive development in response to silicon supplementation. Proceedings of The 5th International Conference on Silicon in Agriculture September 13-18, pp126.

Michael, A. M. (1978). Irrigation Theory And Particle. Vikas Publishing House PVTLTD New Delhi Bombay.

Nigro, F.; L. Schena, A. Ligorio, I. Pentimone and A. Ippolito (2006). Control of table grape storage rots by preharvest applications of salts. Posthar Biol Technol., 42: 142-149.

Ojeda, H.A.; A. Deloire and A. Carbonneau (2001). Influence of water deficits on grape berry growth. Vitis, 40:141-145

Opazo, C. A.; S. O. Farias and S. Fuentes (2010). Effects of grapevine (Vitis vinifera L.) water status on water consumption, vegetative growth and grape quality: An irrigation scheduling application to achieve regulated deficit irrigation. Agricultural Water Management, 97:956-964.

Poinssot, B.; E. Vandelle, M. Bentejac, M. Adrian, C. Levis and A. Pugin (2003). The endopolygalacturonase from Botrytis cinerea activates grapevine defense reactions unrelated to its enzymatic activity. Molecular Plant-Microbe Interactions, 16 (6):553-564.

Porro, D.; M. Ramponi, T. Tomasi, L. Rolle and S. Poni (2010).Nutritional implications of water stress in grapevine and modifications of mechanical properties of berries. ISHS Acta Horticulturae 868: VI International Symposium on Mineral Nutrition of Fruit Crops.

Pradeep, M. M. and S. Elamathi (2007). Effect of foliar application of DAP, micronutrients and NAA on growth and yield of green gram (Vigna radiata L.). Legume Res., 30(4):305-307.

Raese, J. T. and S. R. Drake (2008). Effects of preharvest calcium sprays on apple and pear quality. Journal of Plant Nutrition, 16(9):1807-1819.

Rai, V.K. (2002) Role of amino acids in plant responses to stress, Biol. Plant, 45, 471-478.

Ramteke, S. D.; V. Urkude, S. D. Parhe and S. R. Bhagwat (2017). Berry Cracking; Its Causes and Remedies in Grapes - A Review. Trends in Biosciences, 10(2):549-556.

Romanazzi, G.; A. Lichter, G. F. Mlikota and J. L. Smilanick (2012). Natural and safe alternatives to conventional methods to control post-harvest gray mold of table grapes. Posthar Biol Technol., 63: 141-147. 
Romero, P.; R. G. Munoz, J. I. Fernández-Fernández, F. M. Amor and J. García-García (2015). Improvement of yield and grape and wine composition in field-grown Monastrell grapevines by partial rootzone irrigation, in comparison with regulated deficit irrigation. Agric. Water Manage., 149:55-73.

Shahidian, S.; P. Valverde, R. Coelho and A. Santos (2016). Leaf water potential and sap flow as indicators of water stress in Crimson 'seedless' grapevines under different irrigation strategies. Theor. Exp. Plant Physiol., 28:221-239.

Smith, J.P.; L. M. Schmidtke, M.C. Muller and B.P. Holzapfel (2014). Measurement of the concentration of nutrients in grapevine petioles by attenuated total reflectance Fourier transform infrared spectroscopy and chemometrics. Australian Journal of Grape and Wine Research, 20:299309.

Snedecor, G. W. and W. G. Cochran (1990). Statistical Methods. $7^{\text {th }}$ Ed. The Iowa State Univ. Press, Ames. Iowa, USA, p. 393.

Torrigiani, P.; A. M. Bregoli, V. Ziosi, S. Scaramagli, T. Ciriaci and A. Rasori (2004). Pre-harvest polyamine and aminoethoxyvinylglycine (AVG) applications modulate fruit ripening in Stark Red Gold nectarines (Prunus persica L. Batsch). Postharvest Biology and Technology, 33:293-308.

Upadhyaya, H.; S. K. Panda and B. K. Dutta (2011). CaCl2 improves post drought recovery potential in Camellia sinensis (L) O Kuntze. Plant Cell Rep., 30:495-503.

Wright, H.; J. DeLong, R. Lada, and R. Prange (2009). The relationship between water status and chlorophyll a fluorescence in grapes (Vitis spp.). Postharvest Biology and Technology, 51:193-199.

Yousefi, S.; M. E. Amiri and M. Mirabdulbaghi (2015) Biochemical properties and fruit quality of 'Jahangiri' apricot fruit under calcium chloride treatment. Int J Agron Resear 48: 81-94.

$$
\begin{aligned}
& \text { تأثير مستويات الرى مع الرش الورقى بالسيليكون والكالسيوم والاحماض الامينية على التي }
\end{aligned}
$$

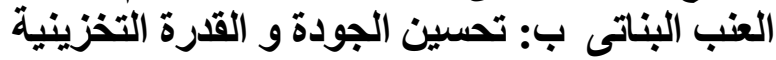

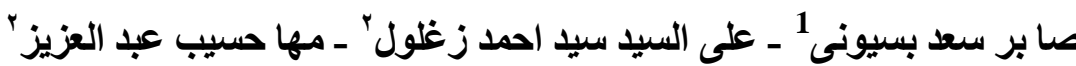

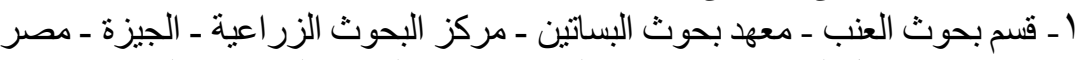

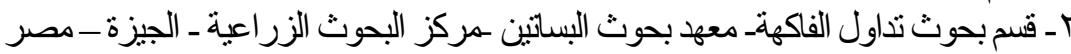

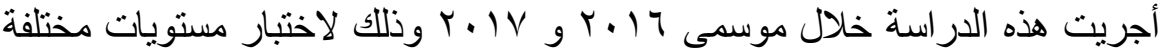

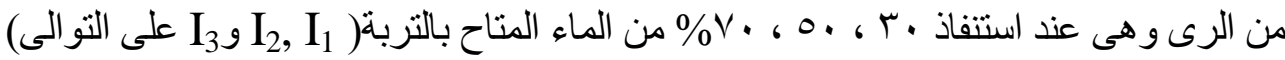


بالاضافة الى معاملات الرش وهى المقارنة (الكنترول) والرش بسليكات البوتاسيوم (اكسيد

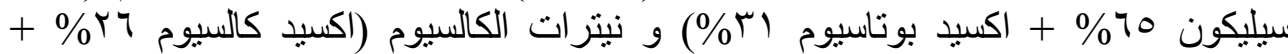

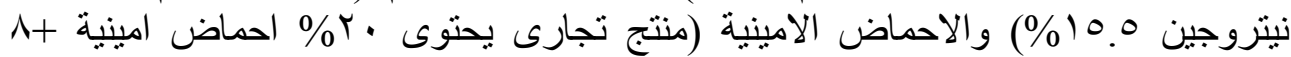

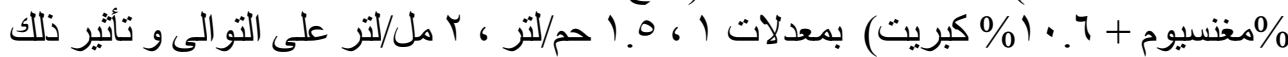

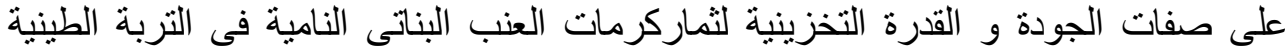

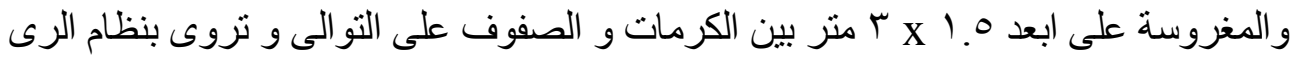

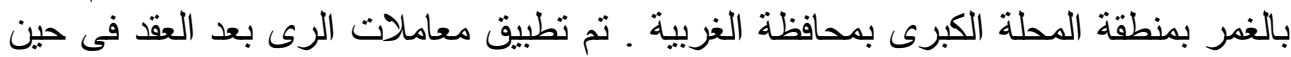

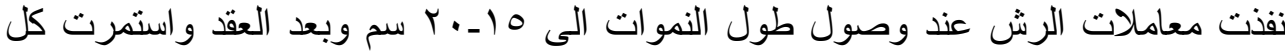

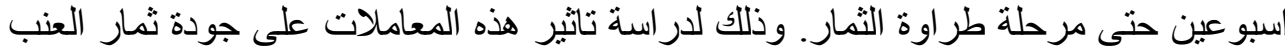

اثناء التخزين البارد.

• اوضحت النتائج تأثر كل من صفات جودة العناقيد والحبات بمستويات الرى المستخدمة حيث

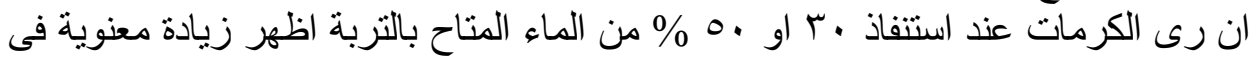

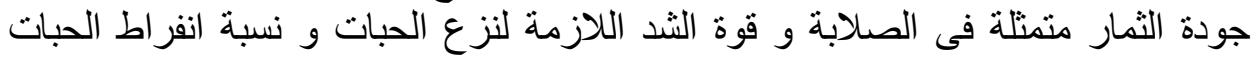

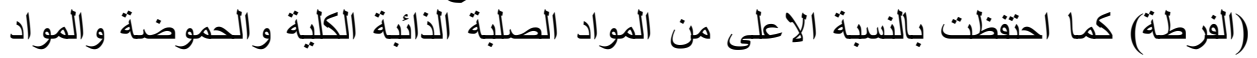

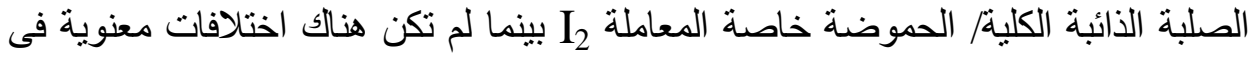

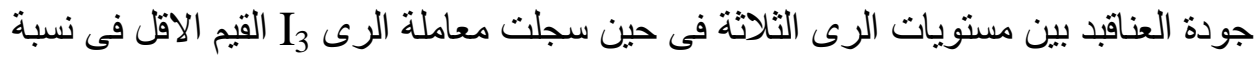
الفقد فى الوزن حتى نهاية فترة التخزين البارد.

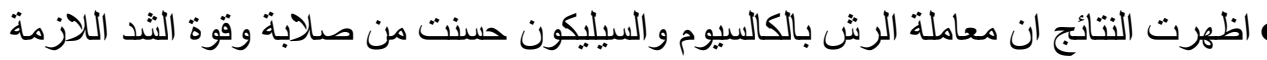

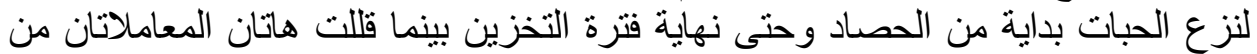

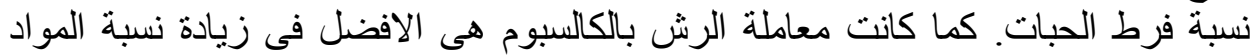

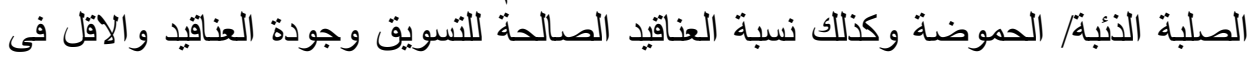
نسبة الققد فى الوزن في نهاية فترة التخزين مما يحسن القدرة التخزينة التئية للثمار

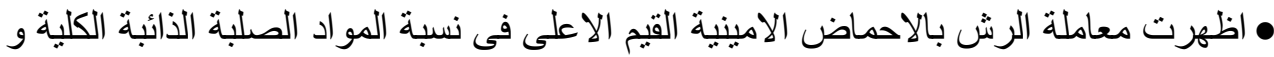

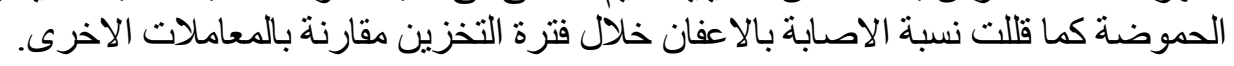

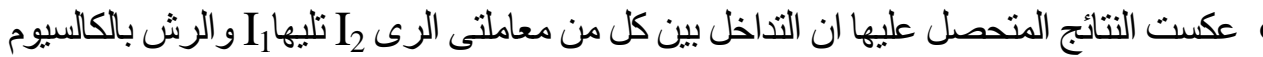

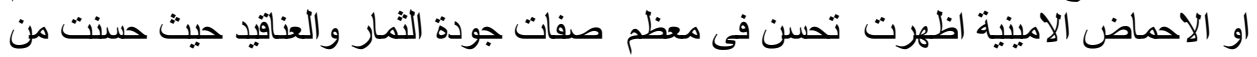

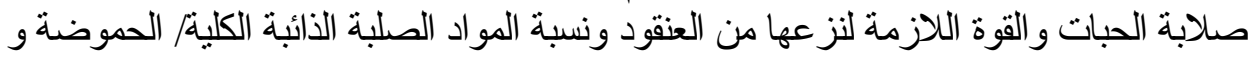

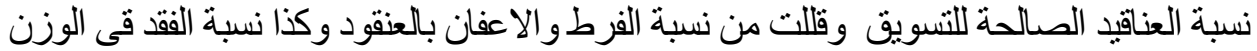

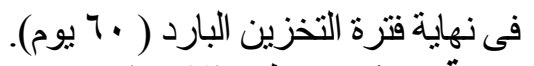

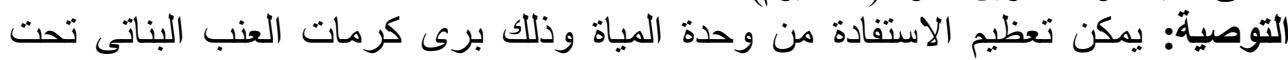

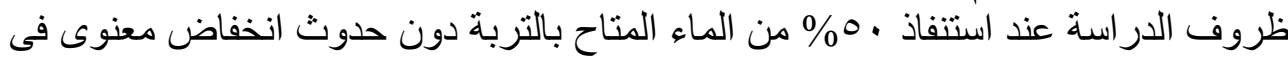

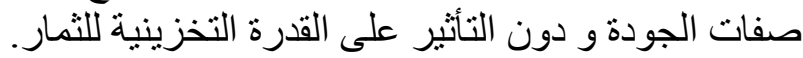

